\title{
The Influence of Promotional Activities on the Success of Retail Business: A critical review
}

\author{
Okonkwo Jeremiah Chukwudi*, Abdoulraman Aljounaidi \\ Al-Madinah International University, Taman desa Petaling 57100 Kuala Lumpur Malaysia.
}

\begin{abstract}
Most businesses have recognized the value of effective promotional work. Throughout the production period, some business firms retained their manufacturing goods in the hope of trade. We believed that customers or consumers will purchase them if the commodity becomes available. But new findings have shown that the company obtains returns that impact the company's success to the benefit within the organization among the opposite strategic resources we have in marketing, but only a promoting operation that generated rapid sales. such as advertisement, personal sales, Sale promotion, and public relations. Enriched and improved marketing and private sales efforts are to be enforced by effective promotional activities, and in each manufacturer and consumer, they are promoted. Marketing strategies such as promotional activity need to be implemented as soon as the market is competitive in full, the terms "fittest" survival is applied and the competition within the enterprise, in an alternative to survival, most organizations follow wholesale live methods for attracting and maintaining clients, e.g. Since one company may not be the sole producer or the sole seller of a product, it is important that the company also exists in the market and updates its practices continuously based on customer request.
\end{abstract}

Keywords: Promotional, Marketing, consumer, Retail Business, Personal Sales

\section{1: Introduction}

Presently, promotion and the customer satisfaction has been increased drastically in resent year marketing industries. The major drawn back is how to build the strong customer relationship is one of the major competitive in marketing sectors. Connection between people relation opinions and customer loyalty are two essential drivers for strong customer relationship management (Hsieh \& $\mathrm{Li}, 2008$ ). All business markets have become very competitive in today's business world, and all companies are already trying to capture more consumers through the market. The only way to increase success in this case is by providing customers with the right information and constantly changing their perception and attitudes to the product offered by the company. Retail's success includes promotions for the sale of products to customer through channels like supermarkets, malls, kiosks, sales machines, or alternate fixed locations (Suguna \& Mathipoorani, 2016). In other terms, marketing for clients tries to sell over the internet, mail, or website. The performance classified by the outcome of the promotional activity which involves implementing components of the marketing standard combine (product, location, price, and promotion) is crucial for retail business achievement (Suguna \& Mathipoorani, 2016). Clarifying the final section in the retailing cycle which focuses on the exchange of financial products and services for functions of the seller, usually of a store or service institution, and therefore of individual shopper to the seller (Davidson \& Block, 2015).

Although merchandising business is prima facie associated with the final word shopper, one of the many different means through which the shopper receives products and services is to be known as one of the businesses (Obaga, Omido, Garashi, Odera, \& Ogutu, 2013). Shopper spending, which may have historically evolved more and more in terms of merchandising structure, is being entertained more and more by alternative variety of consumer markets in which each non-public and profit enterprise is strongly supported by spreading. The merits and consequences of promotional work are underlined. Successful promotional activity has become a critical inspiring perspective on the retail world, whether business or another enterprise. In principle this entails the satisfaction of both internal and external stakeholders and involves four primary activities: designing the right mix of community features and services. In terms of expression survival of the most suitable items, the producers use entirely different means and advertising strategies to enjoy their customers and to maintain their position in these bottle neck competitions. several advertisements impact the company sponsorship increases the revenues (success) of the successful retail 
DOI: $\underline{10.51386 / 25815946 / \text { ijsms-v4i3p113 }}$

business because of sales and the group sees the benefit and is assured to support specific business. This has many effects on advertising that enhance the profits (success) of the retail business's competitor as customer support is in line with the sale business and the community sees its advantage and is bound to sponsor certain companies (Suguna \& Mathipoorani, 2016).

Promotion covers all the activities and procedures to convey buyers and sellers together; emphases on answering to consumer demands and competitive positioning; is a continuous coordinated set of activities associated with efficient distribution of products to high potential markets; and involves making decisions about the product, branding, price, market segmentation, promotion and distribution'. Furthermore, Horner and Swarbrooke (1996) contend that destination marketing contains using tourism as a means to an end rather than an end in itself for reasons comprising: enlightening the image of an area to attract industrialists; increasing the range of facilities and amenities available to the local community; giving local residents more pride in their local area; providing a rationale and funding for improvements to the local environment; and trying to make the destination politically more acceptable to outsiders. The review discussed a detail of promotional activities in marketing firm, advertisement, the role of advertisement in the marketing, a brief illustration of sales and personal sales and public relation in marketing tools and a broad overview of the business strategies in marketing activities.

\section{1: PROMOTIONAL ACTIVITIES}

Sales are a difficult task in today's era. The rivalry may be high. Many substitutes may be available. Products are increasingly consumer oriented. Consumers are becoming more mature. For example, at a fair price, they have the best products. The products are better than the alternative for sale. Sales are not automatic, however. The first idea is for sales. output. When the consumers do not know about our products how will they get them? People therefore need to know the nature and quality of the medication. Only good propaganda will make this possible. The right flow of information together with goods from manufacturers to consumers is significant. The marketing communication cycle is thus aimed at educating, persuading, and influencing people. The declaration "Nothing happens until something is sold" brings in short, the position of promotional activities in today's market.

Promotion is to persuade and encourage people, associations, or organizations to buy a good or services from a marketing mixture or elements (Solomon, Surprenant, Czepiel, \& Gutman, 1985). Five primary communication tools: publicity, personal sales, promotion, public relations, and direct marketing are the mixture of advertising campaigns for promotional purposes (Fill, 2006; Fill \& Turnbull, 2019). A structured action plan that includes incorporating skills and knowledge to achieve organizational vision and task reports that typically lead to organizational objectives and priorities (Nzelibe \& Ezekiel, 2019). Promotional business enables brand managers to identify holes and market opportunities and allows companies to track the impact of previous marketing communications. Promotional targets arise both from marketing and business (Fill, 2006). Promotional behavior is however a marketing strategy which has to do with selecting the target market and creating a suitable promo mix to influence and persuade consumers to boost organization's performance (Neslin, 1989; Nzelibe \& Ezekiel, 2019). The efficiency of retail companies can be improved by an understanding of the tasks to be performed by promotional activities (Blattberg, Briesch, \& Fox, 1995; Kuntner \& Teichert, 2016). Promotional activity is defined as marketing activities, such as awareness-raising or positive attitudes towards an organization or products (Blattberg \& Neslin, 1989, 1990; Tan \& Bogomolova, 2016). Organizational performance requires an organization's actual output or results as determined by its planned outputs (or goals and objectives). The organizational performance, (Richard, Devinney, Yip, \& Johnson, 2009), covers three specific areas of corporate outcomes: (a) financial success (profits, return on assets, return on investment, etc.); (b) market results (sales, market share etc.) for company products; and (c) investor return (total return of shareholders, value added etc.). According to (Lucianetti, Battista, \& Koufteros, 2019; Upadhaya, Munir, Blount, \& Su, 2018), the term organizational performance is broader. Experts in several fields deal with retail sector success, including strategic consultants, corporations, accounting, law, and organizational growth.

Retail businesses play an important role in our everyday lives and successful retail business thus constitutes a key component for developing countries. For example, retail companies and institutions are seen by many economists as a tool to measure economic, social, and political development. Over the years other prominent 
DOI: $\underline{10.51386 / 25815946 / \text { ijsms-v4i3p113 }}$

writers have seen promotional activities (advertisement, sales, selling promotion, public relations, and direct marketing), including raising demand, boosting sales, increasing profits, rising market penetration and competitors ' activities (B. Ayuba, 2019; B. Ayuba \& Aliyu, 2016; Sunday \& Ayuba). Promotion politics, on the other hand, are the rules and guidelines of a company or organization that describe the way people interact in the promotion of a good or service with potential customers. The advertising strategy helps the company to keep track of the message it sends about products or services and to identify appropriate actions for employees when interacting with external staff. General Juice Plc, for example. Could have a strategy to ensure that, if they meet with clients to promote a product or service, they believe representative would comply. The bonuses were aimed at the household managers, as they were told the last thing about where the disposable income would be spent. In each customer demographic climate, marketing department has the task of deciding the best promotional activities it can hire.

Several previous studies have shown mixed results in different contexts and countries, and different variables. According to research by (Austin \& Pinkleton, 2015; Shah et al., 2012), which was aims at examining the impact of publicity on consumer brand preferences, identifying advertisement channels that influence consumer buying behavior most effectively and identifying factor that encourages consumer brand loyalty, The study found that branding in a lifestyle was linked to high language abstractions; branding in a product was linked to linguistic precision; and construal level was a mediator, which increased willingness to pay at low levels, the research recommended that careful consideration for future studies be required to use descriptive terminology and lifestylebased publicity. In another research by (A. J. Lee, 2019) which was the purpose of the research is to investigate the dynamic asymmetric impact on the purchasing process of cross-medium exposures, the findings suggest that through the cross-media was the overall effect of television advertising was complex based on its alignment with the previous online visibility, the study suggested study complex synergistic effects that showed asymmetry against TV publicity.

Research by (Parsons \& Descatoires, 2016)which was aims to assess the quality of shopping mall offers and consumer reviews, results indicate clear differences between sellers and consumer and indicate possible combinations that would produce optimum customer comportment, the studies recommend Some conventional promotions. Research by (Belch \& Belch, 2003; Blattberg \& Neslin, 1990) which was the aim to examine the drugs as commercial products, is subject to diverse marketing methods including promotional activities, and to investigate the patients' opinions on the promotional activities of pharmaceutical companies, the result shows Nearly $83 \%$ of the participants were aware of the promotion issue. Eighty percent found it unethical, $82 \%$ suggested that promotional activities should be forbidden, restricted, or regulated. 1/3 of the participants believed that physician made their drug choices based on the gifts \& ads of pharmaceutical company. Half of them had low confidence in the prescriptions of physicians who accepted gifts from pharmaceutical companies. $54.5 \%$ of patients also considered promotional activities as a factor that increased drug prices, the study recommended future research, Further, these regulations must incorporate and take into consideration the patients' opinion.

The importance of this study is represented in determining the effective promotional activities affecting the success of the retail business. It shows the significant relationship that exists between promotional activities and the success of the retail business with the understanding of the best activities for sustainable success. This study contributed significantly to the application of the five independent variables: advertising, personal selling, direct marketing, sales promotion, and public relations and its impact on the Success of Retail Business (SRB). The importance of this study is useful to many bodies such as General Juice Plc, where stands to gain or to know the right blend of promotional activities (advertising, directing marketing, personal selling, sales promotion, and public relations) that should be used at a good time, and on the right stage of the Product Life Cycle (PLC), and the feedback about their product to remain competitiveness in the market. Also, research of this nature is not only going to be relevant but also very significant, especially at a time when every effort is made to increase profit, sales volume, increase in market share of the organization (Churchill \& Iacobucci, 2006; Key \& Czaplewski, 2017). This is research important for Marketing Manager It helps marketing managers to better understand the value of publicity (advertising, direct marketing, sales promotion, and public relations) for the company and the need to plan their promotional strategies systematically and strategically, considering the limited resources available. in addition, this 
DOI: $\underline{10.51386 / 25815946 / \text { ijsms-v4i3p113 }}$

is research important for Companies, because helps companies in building up a sound promotional activity element to retain or capture potential or existing customers that will enable them to remain competitive in the market. For Potential/Existing Customers the important for this research in Promotional activity can make potential/existing customers aware of their products and services which normally lead to a more effective market, as consumers have more information available to them. Knowledge of a product or service increases consumer choice, leading to stable prices and improve profits, sales volume, market share. For Government, the government will benefit in terms of taxes to be paid as part of fundraising by the government (Gregory, 2020).

The relationship between the variables of this study will contribute to acknowledging the effect of promotional activities continues to be questioned by many managers/sector holders, especially those with a lower level of marketing confidence. The study will generate further debate and will likely include some answers on the impact of promotional activities on the growing retail business. The findings should provide many brand executives with a solid base for allocations. While this study is arguable, the importance of the economy can be seen in the use of promotional resources that create value for clients. As every promotional activity is primarily aimed at affecting sales and testing of new products, increased sales are expected to flow into the "ceteris paribus" benefit. In addition, the state collects tax revenue (Camilleri, 2018). Marketing, in a social sense, is any kind of trade to suit men. Marketing in a corporate context is a business activity system designed to plan, sell, promote, and deliver goods and services that satisfy the needs of the market (Odugbesan \& Osuagwu, 1999). Marketing is the tool by which an organization can accomplish its short mission, goals, and strategic priorities in the face of change in the long term (Stoelhorst \& Van Raaij, 2004). In view of the above points, marketing can be concluded as the strategic method for identifying current and future needs and producing goods and services that can effectively and efficiently satisfy the target consumers or customers.

\section{2: Advertising}

The form of marketing, which is distributed through a mass-media, can be described as advertisement. The sponsor should clearly be defined, and the publicity may relate to a business, a product, or a service (French, Ryan, \& Mayson, 2016). To promote and advertise a product, service, or concept (Brassington \& Pettitt, 2000) describe advertisement as a paid non-personally personal communication directed at target people and transmitted by various media. The key difference between ads and other promotional resources is that they are impersonal and interact through paid media outlets with many people. Via mass media like the newspapers, the magazines, the television, or the radio, Phillip Kotler defined advertisement as any paid way of non-personal presentation or promotion of ideas, products, and services.The advertising institute (IPA) has described advertising as how the most compelling message for the right perspective will be delivered at the lowest possible cost.

\subsection{1: Types of Advertising}

1. Pioneering advertising: Instead of a specific brand, it is trying to develop primary demand for a primary product class. The adoption process needs to be completed at an early stage. Its fundamental role in informing and not convincing. The brand of a particular company must not be listed at any cost.

2. Competitive advertising: Instead of creating a product category, a company can be pushed into a competitive adversary as its product life cycle continues to resist product and marketing to its rivals.

3. Reminder advertising: Try is to retain to the public the identity of the good or service. If the product or service has achieved brand preference, it can be useful. Soft selling advertisements can be used, which simply mention the name or show the name as a reminder (Barker/Michael, 1992, P.327).

4. Institutional Advertising: Large companies sometimes advertise their general activities like the public service rendered by them without mentioning their specific product. This is described as institutional promotion and aimed at building a positive image or attitude towards the company and thus ultimately its products (Kotler, 1994). Institutional advertising is used to display or promote the identity of a company and its key products or services. The goal is that the public, especially potential users of their products and services, receive increasing support (McCarthy, 1986:574).

5. Cooperative Advertising: Manufactures at times cooperate with their whole sellers and retailers by giving them an advertising allowance for their local advertising so that the manufacturer's own brand 
DOI: $\underline{10.51386 / 25815946 / \text { ijsms-v4i3p113 }}$

Volume: 4 Issue: 3

May to June 2021

www.ijsmsjournal.org

may get preference in such advertising. The producer pays to distributor or retailer concerned a proportion of advertisement costs.

\subsection{2: Roles of Advertising in Marketing}

According to (B. Ayuba, 2014; B. Ayuba \& Kurfi, 2013; H. Ayuba \& Baita), advertisement, the connection between the goods and supplier resources in relationships to market realities, can play an important role in ensuring that they can convey information appropriately to customers. Frances \& Stephen (2006), advertising help to enlighten the audience about the quality of the product and consequently create such product or act favorably towards such service or idea. Advertising helps to change the state of ignorance to that of awareness and enlightenment. Much business organization use advertising to create disposition or improve a fault identity. The great advantage and the role of advertising is that it transmits its promotional message to a great number of people, likely to people that the advertiser does not know or cannot reach.(Fill, 2006) suggests that when a normal or desirable frame of reference already exists, advertising can affect the product and brand selection.

Publicity increases the return on revenue. It not only affects the brand's sales but also the sales of other brands. This requires companies to increase their budgets to retain their share of the market. The purpose of ads is essentially to stimulate demand.

\subsection{2: Stages in Advertising Campaign}

According to (B. Ayuba, 2014), a well-managed campaign includes five stages: Stage 1: Set promotional goals, Step 2: Set advertising budget -marketers should remember that ads have a role in generating demand. The sum spent on promotional should be important to the future success of the business. Stage 4 -Decide what advertising medium to use (radio, television, social media, the Web, etc.), stage 5: assessment of the outcome of the advertisement (meaningful clients will consider the appropriate message, distinctive censorship of the customer's attention, reveal able a difficult task).

1. Advertising Expenditure: (O'Guinn) decisions about advertising expenditure usually must be made in conjunction with assessment about the position of the product in its life cycle of the product is at the introductory stage, a considerable number of resources will be put into advertising. There are various options open to an organization in deciding how much to spend on advertising its products it could decide to adopt a percentage of sales approach, where advertising expenditure is related to sales resources. Thus, it has the benefit of relating expenditure to sales, but it discourage innovative approaches to advertising expenses and does not allow for difference to be made between products or sales territories. It is relatively a crude way of allocating such expenditure. Another approach to advertising expenditure is to base it on what the competition is spending such as media expenditure etc.

2. The Advertising Message: Probably the most important aspects of any advertising campaign are the decision about what to say to prospective customers and how to say it. According to (Lamb, Hair, \& McDaniel, 2000), They said a message conveyed in media advertising targets acts as guidance for the entire advertising program's preparation and execution. This helps customers to buy new items at time.

\section{1: Personal Selling}

Personal selling is an advocacy combination that allows advertisers to face consumer contact to sell their product to the customer. This component of the promotional mix has the elements of feedback message or response about the quality of the product. (Ross \& Harradine, 2010) describe personal sales as a two-way communication mechanism between an organization's representative and an individual or community with a view to informing, persuading, or recalling, or serve them in taking proper action. Personal sales are also a key element in maintaining customer satisfaction and building long-term, confidence and understanding buyer-seller ties.(Verhallen, Greve, \& Frambach, 1997) reported that increased competition has contributed to the establishment and preservation of established relationships with consumers within the rapidly evolving world of quality products. Moreover, Julian \&(Ramaseshan \& Patton, 1994) notes that long-term relationships between individuals are a major factor in achieving a competitive advantage for manufacturing companies. (Arthur Meidan, 1996) notes that it is unlikely that if a customer chooses a new product. Personal sales are therefore probably the most critical factor in the manufacturing contact cycle. (H. L. Lee, 2002) states that personal sales can be made either directly or using digital instruments such as the Internet. Personal sales are oral contact with potential product buyers to sell and establish a 
DOI: $\underline{10.51386 / 25815946 / \text { ijsms-v4i3p113 }}$

Volume: 4 Issue: 3

May to June 2021

www.ijsmsjournal.org

connection. The priority of personal sales may be the development of a connection with the potential buyer, but inevitably the end of the sales must end" (B. Ayuba, 2019).

\subsection{1: Sales Promotion}

Brassington \& Pettitt (2000) says that promotional promotion is various methods of tactical marketing, most of which have short-term incentives, intended to give added value to the product or service to achieve sales or commercial aims. (Arthur Meidan, 1996) also states that it has two characteristics. First, it gives "a negotiating opportunity," as there is an appealing quality for many sales promoters that provides a deal that is not yet available for purchase. The disadvantage, however, is that even though a significant number of customers are attracted, other clients appear to be less committed to brands in the long term. Secondly, if sales promotions are used too frequently and carelessly, they can lead to unsafe customers and worry about a reliable or reasonably priced service. The promotion of purchases aims at giving consumers additional value as a reward for immediate sales. This incentive can be aimed at customers, distributors, and sales representatives. Purchase's promotions may be an important part of the messaging or advertising mix and are often strategically important in the rapidly changing market for consumer goods for the number three and four brands (Fill, 2006).

The promotion of sales is a method aimed at increasing the selling of a product or services. This may include a promotional campaign, increased effort for public relations, a free sample campaign, the selling of free gifts or trade stamps, the organization of presentations or exhibitions, contests with desirable awards, temporary cuts in price rates, door-to-door calls, informal telemarketing letters and other means (B. Ayuba, 2014). Promotional sales are initiatives designed to increase demand or promote product purchase during the time defined by Michael, Gray and Elnora (2009).During 1988 Kotler also saw the promotion of sales as "consisting of a diverse collection of incentives, mostly short term, design to stimulate on the trade. He went on to say that advertising offer reason to buy while sales promotion offers incentives to buy. He listed the tools of sales promotion to include:

1. Consumer Promotion: This includes samples, coupon cash refund, and price off contest demonstration, premises warrant, free trail, patronage reward and prizes.

2. Trade Promotion: This includes buying allowance, free goods, merchandized allowance, cooperative advertising, advertising and display allowance, push money, dealer's sales contest allowance.

3. Sales Promotion: Bonuses, contest, sales rallies etc. (Ode, Babayeju, \& Obalowu, 2013) defined sales promotion as any activity undertaken to help promote the sales of a commodity, especially from the producer, wholesalers and retailers outlet.

\subsection{2: Incentivize Purchases with Sales Promotions:}

Sales promotions are marketing activities that provide prospects with an incentive to buy by adding value to the product. Examples of commonly used sales promotional tools include discounts, gifts, contests, premiums, coupons, and rebates. This promotion tactic is often used to build loyalty among existing customers and offers new customers a low-risk reason to purchase. One of the major benefits of sales promotions is that they are a great way for businesses to quickly increase their revenue in a short period of time. When tied to a specific event or holiday, such as Valentine's Day or the end of the school year, for example, sales promotions can be quite successful. However, businesses need to be careful that they do not make customers dependent on sales promotions. Sometimes, offering too many promotions causes customers to hold out and wait to make a purchase until they receive added value.

For the small business selling environmentally friendly clothes, a sales promotion may be to offer a buyone-get-one special during the holiday season or to offer free shipping with the purchase of a certain dollar amount.

\section{2..1 Public Relations}

It is a broad set of communication activities that is used to create and maintain favorable relations between the organization and its public at no charge (most of the time). Public relation is communication in news story form, regarding organization or its products or service which is transmitted through a mass medium at no charge (Davis, 1997). It needs to cultivate effective media relations and targeting publicity to key markets area viewed as the highest priorities. According to Kotler, public relation is defined as a planned effort by an organization to influence some group's attitude or opinion towards that organization. The target market of the public 
DOI: $\underline{10.51386 / 25815946 / \text { ijsms-v4i3p113 }}$

relations effort may be any given public such as customers, a government agency or people living near the promoting organization. (Kotler, 1994) Public relation influences the opinion of various groups. It can show the company to be a leader in its industry or as an innovator. It can illustrate the company's public spirited and aware of social responsibilities. Public relation uses similar media to that of advertising, however, unlike advertising; it does not normally promote a single theme. It is highly specialized activity requiring a constant flow of press release about the company, its operations, products or services and employees. These are adapted to the needs and styles of the chosen medium. It is also a sophisticated technique of communication to a much wider range of audiences then advertising or sales promotion. Nevertheless, it must form an integrated part of the entire communication mix and indirectly support its sister activities in this mix (Ibid).

The advantage of public relations is that a strong impact it can have on public awareness at a much lower costs than do advertising. The company does not pay for the space or time in the media. Rather, it pays for a staff to develop and circulate information and to manage events. If the company develops an interesting story, it could be picked up by several different media, having the same effect as advertising that would cost millions of dollars. And it would have more credibility than advertising (Kotler, 2003, P.516). Despite its potential power, public relation is often described as a marketing stepchild since of its limited and scattered use. The public relations department is usually located at corporate headquarters. Its staff is so busy dealing with various public's-stockholders, employees, legislation, city officials' public relations program to support product marketing objectives may be ignored. Marketing managers and public relations practitioners do not always talk the same language (Ibid).Public relations include building good relations with the public by obtaining favorable publicity, building a good corporate image, or avoiding unfavorable publicity.

According to (Ahmed, 2019), An effective way for small businesses to create a favorable brand image is through sponsorship within the community. A common misconception is that sponsorship require a large financial investment. However, a small business on a budget can create a name for itself in its neighborhood by sponsor small activities like kids' soccer games or a festival lunch for a local association. A further reviewed Michelle Seidel, B.Sc., LL.B., MBA (2019), states that public relations involve developing a favorable image for the brand in the media, with the goal of building brand awareness and increasing sales. Typically, media coverage is not paid for by the business. Public relations activities include press releases, press conferences, sponsorship, and media interviews. This promotional tool is an effective way to conduct damage control if your business has developed a bad reputation or is facing criticism in the media. Public relations are also used by businesses to build goodwill in the community by offering time, money through sponsorship or free and low-cost products and services to specific groups.

Keep in mind that media coverage is not something many businesses can control. While the goal of public relations is to develop a favorable image in the media for prospects to take note, it is possible that the message can miss the mark or not reach prospects at all. Businesses use public relations to build brand awareness and create a good impression in the public eye. Public relations vehicles include press releases, press conferences, sponsorships, and media interviews. Public relations can also be used for damage control. If the business is involved in some poor publicity, a strategic public relations campaign can bring its reputation back on track.

\subsection{1: Success of retail business}

Retail business is comprised of the promotional activities related to selling products directly to consumers through channels such as stores, malls, kiosks, vending machines, or other fixed locations (Suguna \& Mathipoorani, 2016). In contrast, direct marketing to consumers attempts to complete a sale through phone, mail, or website sales. The success categorized by the outcome of the promotional activities which is an implementation of the components of the traditional marketing mix that comprises of (product, place, price and promotion) is essential for success in retail business (Suguna \& Mathipoorani, 2016). (Davidson \& Block, 2015) clarify retailing as the final part of the marketing process in which the various functions of the seller, usually a store or service establishment, and the buyer, an individual consumer is primarily oriented to accomplishing the exchange of economic goods and services, for purposes of personal, family or household use. Although retailing business deals predominantly with the ultimate consumer, it must be recognized that the retail store is only one of several alternative means by which consumers 
DOI: $\underline{10.51386 / 25815946 / \text { ijsms-v4i3p113 }}$

Volume: 4 Issue: 3

May to June 2021

www.ijsmsjournal.org

can obtain the products and services they desire (Obaga et al., 2013). Increasingly, consumer expenditures that might have usually gone through the retailing arrangement are being diverted to other types of use markets which are being aggressively served by a variety of both private and public enterprises.

Retail business have an important role in our daily lives and therefore, successful retail business represents a key ingredient for developing nations. Thus, many economists consider retail business and institutions like an engine in determining the economic, social, and political progress. Over the years, some notable authors such as (B. Ayuba \& Aliyu, 2016; Fill, 2006; Porter \& Kramer, 2002), have regarded the promotional activities (advertising, personal selling, sale promotion, public relation and direct marketing) as having such roles as stimulating demand, boosting sales in a particular geographical area, improving profit, increasing market shares, countering competitors activities and retaining customer loyalty or patronage in the retail business. On the other hand, promotional policy is a set of rules and guidelines set forth by a company or organization that outline how employees are to interact with potential customers in the promotion of a good or service. The promotion policy helps the company keep control of the message it is sending about the goods or service, as well as to determine appropriate actions that employees can take when dealing with outside personnel. For example, General Juice Plc. could have a promotion policy that it feels representative must adhere to when they meet with customers to promote a product or service. Promotional activities were to target the heads of the household as they had the final say on where the disposable income will be spent. Marketing department is saddled with the responsibility to determine the best promotional activity to employ in each customer demographic environment. Success of retail business can be defined as the ability of the business to achieve its stated objective. It is the achievement of the business with regards to its business goals (Lucky, Olusegun, \& Bakar, 2012). Business success has traditionally been measured by achievements of the financial goals (Getz \& Carlsen, 2000; Walker \& Brown, 2004), and the growth of the business in terms of revenue (Walker \& Brown, 2004).

(Leković \& Marić, 2015) asserted that enterprise success can be evaluated by the objective (traditional, financial indicators) and subjective (personally oriented) approaches. Success of retail business is exclusively stated by objective measures of success, while success from the perspective of owners/entrepreneurs/managers can be stated by both financial and non-financial measures of success. Success is the consequence of several factors. Success is primarily determined by the characteristics of owners/entrepreneurs/managers as self-efficiency in finding opportunities, persistency and social skills (Markman \& Baron, 2003). The second group of factors includes market possibilities, number of business partners, capital as well as the selected strategy to reach success (Simpson, 2004).(Leković \& Marić, 2015) asserted that one of the ways to define success as a measure in reaching goals is that the choice of goals is the basis for success. Therefore, these goals have three tasks in the success of retail business to form suppositions of success, direct behavior in accordance with success and the operative task as a measure of success. Owners/entrepreneurs/managers differentiate according to set goals, and thus the importance of both economic and non-economic goals has a different role for every individual. Therefore, goals direct attention and behavior, and the choice is directly connected to motivation, since the individual defines and sets goals, so naturally he will try to realize them. Motivation to become an entrepreneur is significantly connected to the criteria for success measurement. The basic supposition of entrepreneurial motivation in the form of self-employment is the aspiration to increase personal welfare. Motives influence the choice of goals, which will be set. Therefore, goals become criteria for success, and owners/entrepreneurs/managers measure their own success by the degree of goals realization. Thus, owners/entrepreneurs/managers that are successful in realizing set goals can be considered successful.

\section{3: The importance of promotional activities on success of retail business}

Advertising activities on retail business success are intended to change the site and shape of the retail business ' demand curve. Business creation is one of the sales features. Nevertheless, advertising campaigns are responsible for business growth and product recognition. Promotional activities are an exercise in interrelated knowledge, conviction, and power, which is to be "informed is persuaded," and possibly also told if a person is convinced. With imperfect competition, promotional efforts are necessary. 
DOI: $\underline{10.51386 / 25815946 / \text { ijsms-v4i3p113 }}$

The need for advertising is growing due to the increase in the physical distance between producers and consumers. The number of potential buyers is also growing, and the business communication problem is increasing. Between the manufacturer and the final customer there are several mid waters and retailers. The details should not only be passed on to the users but also to the intermediaries. The intermediaries, in effect, distribute the goods to the customers. The promotion of retail business success is therefore the essential marketing communication method.

Consumers now put greater focus than on their needs on having satisfaction. When selecting alternate expenses, they are selective. To retain these customers, an organization has the best promotional activity program. Sales are a concern during the economic downturn. Promoting the quality of life and high rates of employment when society is important at the time. The leading goal of setting up a business without any doubt is profit and success, thus maintaining a continuous existence, Lucky said. Olusegun \& Bakar (2015) said. Consequently, a profitable client produces a very fair return on the assets employed. It is the reason this works well without the person being there on a regular basis (Changing Minds, 2016). A critical view of business performance will demonstrate that when it comes to how businesses perceive their overall business success, there is no right or wrong. Their actions will, however, be focused on what they can do (Lucky et al., 2012). Business success is defined as the ability of the company to fulfill its specified aim, according to (Lucky et al., 2012). This is the success of the company in terms of its business objectives. It sets and accomplishes objectives. (Lucky et al., 2012) also recognized that business performance tends to provide efficiency, growth, income, size, liquidity, and market share information, as well as leverage and success/failure information. It provides information about the growth, success, and failure of the company and, most important of all, its profitability. Business progress therefore implies profitability, efficiency, efficiency, success, etc.

(Shamout \& Emeagwali, 2016) recognized the growing retail industry in a strong-speed environment worldwide and retailers currently use all types of promotional activities to differentiate themselves in the market. At the same time, retailers are booming competitively. Owing to population and economic growth, retailers have started to expand marketing to consumers. "Marketing activities are typically specific to a certain time, location or customer group, that encourage direct reaction by buyers or marketing intermediaries through the availability of additional benefits," said (Peattie \& Peattie, 1994). The activities of one or more of them include the application of promotional equipment (e.g., sampling, discounting, marketing, and selling) which influence individuals directly in making quick choices and finalizing their procurement process. Because retailers ' expertise is high, the two main ideas behind these aggressive promotions from the marketer viewpoint are, by motivating successful consumers to continue to maintain their loyal customers, contributing to success in retail. The success of retail business via promotional activities can be made quite easier and accomplishable by the introduction of variables in retail business activities. The conceptual model approach adopted by the retail sector comprises Quick Answer (QR) codes, electronic tags, digital advertising displays, self-checking systems, sales staff, smart kiosks, and a general connection between these technologies with social media and custom networks and applications (Albers, Krafft, \& Mantrala, 2010). It defines the conceptual model approach adopted by the retail sector. The aim of this investigation is therefore to assess the efficiency of promotional activities in General Juice PLC Ameke Enugu, which affect the success of the retail industry.

The main purpose of its creation is to achieve those goals and objectives of the organization, be they manufacturing or service industries, profit or non-profit based. Most companies now work in an absolutely and chaotic climate in Nigeria and around the world. General Juice is one of the multinationals active in non-alcoholic beverages. The Amaeke field branch in Enugu state is the General Juice under this report. The rivalry between manufacturers of non-alcoholic drinks requires an intense implementation of promotions that appeal for sustainable customer support. Beverages Plc in Nigeria. With its various goods, however, it seems to dominate the market. Corporations have difficulties in searching for the best management and promotional practices to boost their performance and the interest of the shareholders. Not only do excellent companies know how, when and when they can perform, but also their ability to implement the chosen promotional decision (Fill, 2006). The use of available resources in which the promotional capabilities of the organization are established in pursuit of the desired goals are needed in a manner this is acceptable and efficient (B. Ayuba, 2014; Englis \& Solomon, 1997; Fill, 2006) 
DOI: $\underline{10.51386 / 25815946 / \text { ijsms-v4i3p113 }}$

Volume: 4 Issue: 3

May to June 2021

www.ijsmsjournal.org

Customers are better educated today, with the multinational company as a whole now becoming incredibly complex. Organizations must define their needs first and that is where promotional behavior begins to satisfy the increasing demand of consumers. To allow a business to succeed on the competitive market of today, it must be more efficient and effective in meeting its customers ' needs through advertising.

However, promotional operation is a marketing strategy that includes selecting the target market and making the most suitable promotional mix to influence and persuade the consumer to boost the quality of company and to raise the shareholder value (Nzelibe \& Ezekiel, 2019).Promotional activity is aiming at the target heads of the household as they had the final say on where the disposable income will be spent. Marketing department is also saddled with the responsibility to determine the best promotional activity to be employed in a giving customer and demographic environment. Over the years, some influential writers, including (H. Ayuba \& Baita; Fill, 2006)(H. Ayuba \& Baita; Fill, 2006; Tandoh, 2016), considered promotional activities such as advertisement, personal sales, sales, public relations and direct marketing, to have roles that stimulate demand and boost sales across geographical areas, raise profit, increase market share, combat competitor policies and retail outcomes table one give illustration of the sale promotion and on consumer perspective (Table 1). In line with this study, the success of General Juice Plc's retail sector (profit, sales volume, market share and loyalty) is influenced by successful promotional activities (publicity, sales, etc.).

Table 1: Literature review on the Promotional Activities

\begin{tabular}{|c|c|c|c|c|c|c|}
\hline No & Author/yr & Objectives & Methodology & Variables & Findings & $\begin{array}{c}\text { Recommendation } \\
\mathrm{s} \\
\end{array}$ \\
\hline 1. & $\begin{array}{c}\text { Semih Semin, } \\
\text { Dilek Güldal, } \\
\text { Nilgün } \\
\text { Özçakar \& } \\
\text { Vildan Mevsim } \\
\text { (2016) }\end{array}$ & $\begin{array}{l}\text { The goal of the study is to } \\
\text { examine the drugs, as } \\
\text { commercial products, are } \\
\text { subject to diverse } \\
\text { marketing methods } \\
\text { including promotional } \\
\text { activities. Although the } \\
\text { legal/moral aspect of } \\
\text { promotional activities has } \\
\text { been discuss in a limited } \\
\text { manner, the patient has } \\
\text { remain the neglected } \\
\text { variable of this equation. } \\
\text { The goal of our study }\end{array}$ & $\begin{array}{l}\text { The researcher employed a } \\
\text { survey of a descriptive study } \\
\text { which was conducted at } 44 \\
\text { primary health care centers in } \\
\text { Turkey and } 584 \text { volunteers } \\
\text { who applied to these centers } \\
\text { were included. A survey } \\
\text { consisting of } 42 \text { questions } \\
\text { was developed with } \\
\text { demographic information in } \\
\text { the first section, and drug ads } \\
\text { and promotion integrated in } \\
\text { the second section. }\end{array}$ & $\begin{array}{l}\text { The awareness } \\
\text { and ethical } \\
\text { evaluation of } \\
\text { patients of the } \\
\text { promotional } \\
\text { activities. }\end{array}$ & $\begin{array}{l}\text { The result of the study Nearly } \\
83 \% \text { of the participants were } \\
\text { aware of the promotion issue. } \\
\text { Eighty percent found it } \\
\text { unethical, } 82 \% \text { suggested that } \\
\text { promotional activities should } \\
\text { be forbidden, restricted or } \\
\text { regulated. } 1 / 3 \text { of the } \\
\text { participants believed that } \\
\text { physician made their drug } \\
\text { choices based on the gifts } \& \\
\text { ads of pharmaceutical } \\
\text { company. Half of them had } \\
\text { low confidence in the } \\
\text { prescriptions of physicians who } \\
\text { accepted gifts from the } \\
\text { pharmaceutical companies. }\end{array}$ & $\begin{array}{l}\text { The study } \\
\text { recommended a } \\
\text { future research that } \\
\text { a considerable } \\
\text { number of patients } \\
\text { were aware of } \\
\text { promotions and the } \\
\text { effects of } \\
\text { promotion on } \\
\text { prescriptions. The } \\
\text { findings of our } \\
\text { study may } \\
\text { contribute to the } \\
\text { development of } \\
\text { effective } \\
\text { regulations on this } \\
\text { issue. Very strict } \\
\text { measures } \\
\text { controlling drug } \\
\text { companies' } \\
\text { promotion } \\
\text { activities must be } \\
\text { formulated. }\end{array}$ \\
\hline 2. & $\begin{array}{c}\text { Ms. Shallu \& } \\
\text { Ms. Sangeeta } \\
\text { Gupta } \\
\text { (2017) }\end{array}$ & $\begin{array}{l}\text { The goal of the study aims } \\
\text { at exploring the various } \\
\text { factors that influences } \\
\text { consumer buying behavior } \\
\text { and purchase decision and } \\
\text { to identify the various } \\
\text { promotional activities used } \\
\text { by the sellers to motivate } \\
\text { the consumer buying } \\
\text { behavior and purchase } \\
\text { decision. }\end{array}$ & $\begin{array}{l}\text { This study is main based on } \\
\text { primary data collected during } \\
\text { a snap survey using the } \\
\text { question designed for this } \\
\text { purpose to know about the } \\
\text { Impact of Promotional } \\
\text { activities on Consumer } \\
\text { buying behavior. In addition } \\
\text { to this secondary data has } \\
\text { also been gathered from } \\
\text { various newspapers, journals, } \\
\text { magazines, and websites. }\end{array}$ & $\begin{array}{l}\text { The factors that } \\
\text { influence } \\
\text { consumer } \\
\text { buying } \\
\text { behavior, the } \\
\text { purchase } \\
\text { decision and to } \\
\text { identify the } \\
\text { various } \\
\text { promotional } \\
\text { activities. }\end{array}$ & $\begin{array}{l}\text { The result of the study findings } \\
\text { has been made through snap } \\
\text { survey analysis which consisted } \\
\text { of } 200 \text { consumers in the } \\
\text { market. The questionnaire } \\
\text { designed for this purpose to } \\
\text { know about the Impact of } \\
\text { Promotional activities on } \\
\text { Consumer buying behavior. } \\
\text { Findings have also been made } \\
\text { theoretical analysis to provide } \\
\text { in-depth analysis into the way } \\
\text { different promotional factors } \\
\text { influence consumers' decision- }\end{array}$ & $\begin{array}{l}\text { The study } \\
\text { recommended that } \\
\text { a regular survey } \\
\text { should be } \\
\text { conducted } \\
\text { regarding } \\
\text { effectiveness of } \\
\text { the promotions as } \\
\text { it is mandatory for } \\
\text { the marketer to } \\
\text { remain updated } \\
\text { with the } \\
\text { customers } \\
\text { demand; cosmetic }\end{array}$ \\
\hline
\end{tabular}




\section{DOI: $\underline{10.51386 / 25815946 / \text { ijsms-v4i3p113 }}$}

Volume: 4 Issue: 3
May to June 2021 www.ijsmsjournal.org

\begin{tabular}{|c|c|c|c|c|c|c|}
\hline & & & & & making processes. & $\begin{array}{l}\text { industry has } \\
\text { immense } \\
\text { opportunities even } \\
\text { for the new } \\
\text { entrants hence to } \\
\text { remain ahead in } \\
\text { competition it's } \\
\text { important to be } \\
\text { updated with } \\
\text { customers ever } \\
\text { changing needs. }\end{array}$ \\
\hline 3. & $\begin{array}{c}\text { Mohammad } \\
\text { Saeed } \\
\text { Muhammad } \\
\text { Anwar } \\
\text { (2016) }\end{array}$ & $\begin{array}{l}\text { The goal of the study is to } \\
\text { determine an Islamic } \\
\text { perspective on promotional } \\
\text { activities. However, there } \\
\text { is a need to develop not } \\
\text { only general guidelines for } \\
\text { achieving marketing goals } \\
\text { and corporate objectives in } \\
\text { a morally acceptable } \\
\text { manner. }\end{array}$ & $\begin{array}{l}\text { The study employed a survey } \\
\text { of the Qur'anic view about } \\
\text { man and his resources should } \\
\text { be the basis for designing } \\
\text { promotional tools and media } \\
\text { strategies. The latter are } \\
\text { meant to instill Islamic } \\
\text { values, construct the } \\
\text { characters of clients and } \\
\text { marketers and support truth } \\
\text { in the society. }\end{array}$ & $\begin{array}{c}\text { One set } \\
\text { consisting of } \\
\text { structural } \\
\text { character of } \\
\text { each category, } \\
\text { such as standard } \\
\text { purchase cycle } \\
\text { and domestic } \\
\text { penetration, and } \\
\text { the other } \\
\text { contain detailed } \\
\text { promotional } \\
\text { movement } \\
\text { information. }\end{array}$ & $\begin{array}{l}\text { The result of the study found } \\
\text { Muslim marketers have to be } \\
\text { conscious of their position and } \\
\text { role in managing marketing } \\
\text { activities and creating } \\
\text { consumer awareness about the } \\
\text { qualities of various products } \\
\text { and services available on the } \\
\text { market, and can go a long way } \\
\text { in contributing to economic } \\
\text { progress and social } \\
\text { development. }\end{array}$ & $\begin{array}{c}\text { The study } \\
\text { recommends a } \\
\text { suggestion and } \\
\text { advise an Islamic } \\
\text { code of marketing } \\
\text { by Muslim } \\
\text { marketers, } \\
\text { corporate leaders, } \\
\text { and Shari'ah } \\
\text { experts to the } \\
\text { ethical behavior in } \\
\text { advertising and } \\
\text { other promotional } \\
\text { activities must be } \\
\text { based on a strong } \\
\text { foundation of } \\
\text { Islamic tenets and } \\
\text { injunctions for } \\
\text { future research. }\end{array}$ \\
\hline 4. & $\begin{array}{c}\text { Ibojo Bolanle } \\
\text { Odunlami And } \\
\text { Akinruwa, } \\
\text { Temitope } \\
\text { Emmanuel } \\
(2016)\end{array}$ & $\begin{array}{l}\text { To examine the effect of } \\
\text { company's promotional } \\
\text { activities on the pricing of } \\
\text { a company's brand. } \\
\text { To assess the effectiveness } \\
\text { of promotion in increasing } \\
\text { the sales revenue of } \\
\text { Nigeria brewery products }\end{array}$ & $\begin{array}{l}\text { This study makes use of } \\
\text { survey research design that } \\
\text { allow for the use of } \\
\text { questionnaires to elicit data } \\
\text { from the respondents. } \\
\text { According to Nworgu } \\
\text { (1991), a plan can be define } \\
\text { as a plan or blue prints which } \\
\text { specify how data connecting } \\
\text { to a given problem should be } \\
\text { composed and analyzed. It } \\
\text { provides the procedural } \\
\text { outline for the conduct of any } \\
\text { given investigation }\end{array}$ & $\begin{array}{l}\text { Product } \\
\text { awareness } \\
\text { Promotion } \\
\text { Organization } \\
\text { Objectives } \\
\text { Promotion } \\
\text { Pricing of } \\
\text { Product } \\
\text { Promotion } \\
\text { Sales revenue } \\
\text { Promotion }\end{array}$ & $\begin{array}{l}\text { show that Nigerian Brewery } \\
\text { Plc consists of equally male } \\
\text { and female member of staff. } \\
\text { There were more of male } \\
\text { respondents than female. It } \\
\text { shows the respondents of } \\
49.6 \% \text { were Single, } \\
41.3 \% \text { of the respondents were } \\
\text { Married, } 3.3 \% \text { of the } \\
\text { respondents were Divorced and } \\
5.8 \% \text { of the respondents fell } \\
\text { under others category. }\end{array}$ & $\begin{array}{l}\text { It is noteworthy to } \\
\text { emphasis that } \\
\text { sales promotion } \\
\text { has short term } \\
\text { effect, therefore } \\
\text { management of } \\
\text { organizations in } \\
\text { the Brewery sub } \\
\text { sector of the } \\
\text { manufacturing } \\
\text { industry should } \\
\text { endeavor to } \\
\text { achieve } \\
\text { appropriate } \\
\text { customer } \\
\text { relationship } \\
\text { management } \\
\text { (CRM). this will } \\
\text { provide up to date } \\
\text { information } \\
\text { relating to } \\
\text { customers' needs } \\
\text { and best ways of } \\
\text { satisfying those } \\
\text { needs. }\end{array}$ \\
\hline
\end{tabular}




\section{DOI: $\underline{10.51386 / 25815946 / \text { ijsms-v4i3p113 }}$}

Volume: 4 Issue: 3

May to June 2021

www.ijsmsjournal.org

\begin{tabular}{|c|c|c|c|c|c|c|}
\hline 5. & $\begin{array}{l}\text { Adedoyin } \\
\text { Hassan } \\
(2016)\end{array}$ & $\begin{array}{l}\text { The goal of the research } \\
\text { was purposely meant to } \\
\text { measure the effect of } \\
\text { advertising on sales } \\
\text { promotion of General Juice } \\
\text { Plc. To Examine how the } \\
\text { company creates awareness } \\
\text { and the impact of } \\
\text { promotional activities in } \\
\text { the juice industry }\end{array}$ & $\begin{array}{l}\text { The study employed a survey } \\
\text { of a Primary sources of data } \\
\text { collection were through } \\
\text { questionnaires and oral } \\
\text { interviews, while some } \\
\text { secondary information was } \\
\text { gathered from the annual } \\
\text { report statistics of General } \\
\text { Juice Plc as at the year ended } \\
31 \text { " December } 2002 \text {. } \\
\text { Fifty (50) written } \\
\text { questionnaires were } \\
\text { presented to a random } \\
\text { sample of } 50 \text { marketing } \\
\text { personnel staff of the } \\
\text { company drawn from a total } \\
\text { of } 247 .\end{array}$ & $\begin{array}{l}\text { Th Effective } \\
\text { advertising will, } \\
\text { and can } \\
\text { improve sales } \\
\text { Promotion, } \\
\text { There are other } \\
\text { factors apart } \\
\text { from } \\
\text { advertising that } \\
\text { can affect sales } \\
\text { promotion. } \\
\text { Effective } \\
\text { advertising is an } \\
\text { important factor } \\
\text { towards the } \\
\text { realization of } \\
\text { the sales } \\
\text { promotion goals } \\
\text { of the } \\
\text { organization. } \\
\text { Advertising has } \\
\text { an effect on } \\
\text { sales promotion }\end{array}$ & $\begin{array}{l}\text { The review of literature of the } \\
\text { sales effect of advertising } \\
\text { which itemized research works } \\
\text { carried out by Notice (1988 and } \\
\text { 1997), Palda (1964), } \\
\text { Montgomery and Silk (1972), } \\
\text { Urban (1975), Callaghan } \\
\text { (1980), Metwally (1980), etc., } \\
\text { reveal that advertising sure has } \\
\text { a link with sales level. } \\
\text { The level of impact is easier to } \\
\text { measure if there are fewer other } \\
\text { factors or a controllable } \\
\text { number of factors which also } \\
\text { have an impact on sales level. }\end{array}$ & $\begin{array}{l}\text { The research } \\
\text { recommended for } \\
\text { future research, } \\
\text { advertising, is } \\
\text { probably because } \\
\text { of its prevalence, } \\
\text { the most well- } \\
\text { known and widely } \\
\text { discussed type of } \\
\text { promotion. }\end{array}$ \\
\hline 6. & $\begin{array}{c}\text { Francesco } \\
\text { Massara, } \\
\text { Daniele Scarpi, } \\
\text { \& Daniele } \\
\text { Porcheddu } \\
\text { (2019) }\end{array}$ & $\begin{array}{l}\text { The research aims at } \\
\text { examining the impact of } \\
\text { publicity on consumer } \\
\text { brand preferences, } \\
\text { identifying advertisement } \\
\text { channels that influence } \\
\text { consumer buying behavior } \\
\text { most effectively and } \\
\text { identifying factor that } \\
\text { encourages consumer } \\
\text { brand loyalty. }\end{array}$ & $\begin{array}{l}\text { The authors have examined } \\
\text { the relationship between the } \\
\text { style of advertisement } \\
\text { (product based versus life } \\
\text { style), advertising (abstract } \\
\text { versus concrete), and the } \\
\text { readiness of consumers to } \\
\text { pay through the construction- } \\
\text { level lens which analyzes the } \\
\text { way consumers perceive a } \\
\text { brand. }\end{array}$ & $\begin{array}{c}\text { The branding } \\
\text { was based on } \\
\text { the language } \\
\text { and the level of } \\
\text { building was a } \\
\text { mediator, which } \\
\text { improved the } \\
\text { availability of } \\
\text { payments at low } \\
\text { level. }\end{array}$ & $\begin{array}{c}\text { The study found that branding } \\
\text { in a lifestyle was linked to high } \\
\text { language abstractions; branding } \\
\text { in a product was linked to } \\
\text { linguistic precision; and } \\
\text { construal level was a mediator, } \\
\text { which increased willingness to } \\
\text { pay at low levels. }\end{array}$ & $\begin{array}{l}\text { The report advises } \\
\text { that careful } \\
\text { consideration for } \\
\text { future studies be } \\
\text { required to use } \\
\text { descriptive } \\
\text { terminology and } \\
\text { lifestyle-based } \\
\text { publicity. }\end{array}$ \\
\hline 7. & $\begin{array}{c}\text { Ronald C. } \\
\text { Curhan } \\
(2016)\end{array}$ & $\begin{array}{l}\text { This research aims to } \\
\text { assess the successful } \\
\text { publicity of the aspect of } \\
\text { promotional activities used } \\
\text { by the COMPANIES } \\
\text { NASCO GROUP }\end{array}$ & $\begin{array}{c}\text { The study reveals the } \\
\text { strategies used in sampling } \\
\text { population (1000) of which } \\
100(110) \text { are selected for } \\
\text { this analysis as a sample size. }\end{array}$ & $\begin{array}{l}\text { Advertising is } \\
\text { relevant in } \\
\text { NASCO group } \\
\text { of companies } \\
\text { Nigeria when } \\
\text { generating } \\
\text { customers who } \\
\text { are interested } \\
\text { and shaping } \\
\text { buying } \\
\text { decisions } \\
\text { effectively. }\end{array}$ & $\begin{array}{l}\text { The estimated } \mathrm{x} 2 \text { result is } 15.3 \\
\text { higher than the tabulated } \\
\text { values, and } \mathrm{H} 1 \text { is therefore } \\
\text { agreed on the basis of the test } \\
\text { carried out using the Chi- } \\
\text { Square techniques. }\end{array}$ & $\begin{array}{c}\text { The study } \\
\text { suggested that } \\
\text { urgently needed } \\
\text { measures should } \\
\text { be taken to } \\
\text { determine } \\
\text { customers ' media } \\
\text { tastes in order to } \\
\text { implement } \\
\text { another effective } \\
\text { client media } \\
\text { strategy }\end{array}$ \\
\hline 8. & $\begin{array}{l}\text { Soo Lee, June } \\
\text { Vakratsas, } \\
\text { Demetrios } \\
\text { (2019) }\end{array}$ & $\begin{array}{l}\text { The purpose of the } \\
\text { research is to investigate } \\
\text { the dynamic asymmetric } \\
\text { impact on the purchasing } \\
\text { process of cross-medium } \\
\text { exposures }\end{array}$ & $\begin{array}{l}\text { The researchers studied the } \\
\text { complex impact in household } \\
\text { buying cycles of cross-media } \\
\text { ads on television and online, } \\
\text { and analyzed single-source } \\
\text { data on cross-media domestic } \\
\text { exposures and transactions in } \\
\text { a China brand of consumer } \\
\text { goods packaged (CPGs). }\end{array}$ & $\begin{array}{l}\text { The structure } \\
\text { and the } \\
\text { potential for } \\
\text { asymmetry in } \\
\text { these impacts } \\
\text { due to shifts in } \\
\text { household } \\
\text { demand over } \\
\text { the procurement } \\
\text { process due to } \\
\text { sequential } \\
\text { exposures. }\end{array}$ & $\begin{array}{l}\text { The findings suggest that only } \\
\text { through the cross-media word } \\
\text { (T TV) was the overall effect of } \\
\text { television advertising }(\alpha \mathrm{TV}) \text {. } \\
\text { The advertising impact of } \\
\text { television was therefore } \\
\text { complex based on its alignment } \\
\text { with the previous online } \\
\text { visibility. }\end{array}$ & $\begin{array}{l}\text { The study } \\
\text { suggested } \\
\text { complex } \\
\text { synergistic effects } \\
\text { that showed } \\
\text { asymmetry } \\
\text { against TV } \\
\text { publicity. We also } \\
\text { propose evidence } \\
\text { that the cross- } \\
\text { media response to } \\
\text { future research is } \\
\text { regional variation. }\end{array}$ \\
\hline 9. & $\begin{array}{l}\text { S.A Delre, } \\
\text { W. Jagar, } \\
\text { T.H.A } \\
\text { Bijmolt\& }\end{array}$ & $\begin{array}{l}\text { During the early stages of } \\
\text { the consumer life cycle, the } \\
\text { purpose of this analysis is } \\
\text { to analyze the marketing }\end{array}$ & $\begin{array}{c}\text { This study proposes an } \\
\text { agent-based survey model } \\
\text { that simulates the } \\
\text { effectiveness of various }\end{array}$ & $\begin{array}{l}\text { Many } \\
\text { promotional } \\
\text { efforts are } \\
\text { focused on }\end{array}$ & $\begin{array}{c}\text { The results of simulation } \\
\text { studies suggest that } \\
\text { advertisement events have a } \\
\text { significant impact on dynamics }\end{array}$ & $\begin{array}{l}\text { For future } \\
\text { planning and the } \\
\text { management of } \\
\text { advertising }\end{array}$ \\
\hline
\end{tabular}


DOI: $\underline{10.51386 / 25815946 / \text { ijsms-v4i3p113 }}$

Volume: 4 Issue: 3

May to June 2021

www.ijsmsjournal.org

\begin{tabular}{|c|c|c|c|c|c|c|}
\hline & $\begin{array}{c}\text { M.A Janssen } \\
\text { (2017) }\end{array}$ & $\begin{array}{l}\text { approach and to decide to a } \\
\text { large degree how a new } \\
\text { product is spread. }\end{array}$ & $\begin{array}{l}\text { promotional strategies to } \\
\text { support product launch. The } \\
\text { article focuses on the pacing } \\
\text { and distribution of } \\
\text { promotions. }\end{array}$ & $\begin{array}{l}\text { promoting the } \\
\text { introduction of } \\
\text { new goods. The } \\
\text { optimum } \\
\text { advertising } \\
\text { timing vary } \\
\text { from that of } \\
\text { long-lasting } \\
\text { categories } \\
\text { (white goods, }\end{array}$ & $\begin{array}{l}\text { of diffusion. The conclusions } \\
\text { show: (1) the lack of } \\
\text { promotional support and/or a } \\
\text { mistaken timing of promotions } \\
\text { could result in a product } \\
\text { diffusion failure; (2) the best } \\
\text { targeting strategy should be to } \\
\text { address distant, small, and } \\
\text { coherent consumer groups. }\end{array}$ & $\begin{array}{l}\text { campaigns to } \\
\text { promote the } \\
\text { introduction of } \\
\text { new products such } \\
\text { findings are } \\
\text { recommended. }\end{array}$ \\
\hline 10. & $\begin{array}{l}\text { Rosanna Garcia } \\
\& \text { Paul Rummel } \\
\quad(2019)\end{array}$ & $\begin{array}{l}\text { The purpose of this } \\
\text { research is to recognize } \\
\text { and define validity } \\
\text { important to this modeling } \\
\text { community. }\end{array}$ & $\begin{array}{l}\text { Methods for model } \\
\text { instantiation with joint } \\
\text { partwords and model } \\
\text { calibration are illustrated by } \\
\text { means of the joint first choice } \\
\text { rule. The model will be more } \\
\text { assured that the adjustment is } \\
\text { accomplished when it } \\
\text { follows the findings of first } \\
\text { choices for customer } \\
\text { preferences. The model is } \\
\text { one step closer to the } \\
\text { validation when verification } \\
\text { repeats stylized facts in a } \\
\text { macro level. }\end{array}$ & $\begin{array}{l}\text { The IT industry. } \\
\text { Changes in } \\
\text { business and } \\
\text { sector }\end{array}$ & $\begin{array}{l}\text { The findings of this study are a } \\
\text { macro replica of stylized } \\
\text { reality. The developer is a step } \\
\text { towards validation. Since joint } \\
\text { data findings are both } \\
\text { individual and aggregate, this } \\
\text { kind of empirical data } \\
\text { collection is suitable for agent- } \\
\text { based marketing models. The } \\
\text { model should feel confident } \\
\text { that calibration is accomplished } \\
\text { if the models conform to the } \\
\text { results of the rules for first } \\
\text { choosing consumers ' } \\
\text { preferences. }\end{array}$ & $\begin{array}{l}\text { The work has } \\
\text { shown how joint } \\
\text { studies can be } \\
\text { employed to } \\
\text { instance and } \\
\text { calibrate an agent- } \\
\text { based marketing } \\
\text { model, according } \\
\text { to historical } \\
\text { models of the } \\
\text { industry } \\
\text { evolution. }\end{array}$ \\
\hline 11. & $\begin{array}{c}\text { Tongil "TI" } \\
\text { Kim \& Diwas } \\
\text { KC } \\
(2019)\end{array}$ & $\begin{array}{l}\text { The goal of this study is to } \\
\text { explore a demand model to } \\
\text { analyze the effect of a } \\
\text { hospital advertising ban, } \\
\text { which policy makers have } \\
\text { recently taken into } \\
\text { consideration. }\end{array}$ & $\begin{array}{l}\text { The study examined the } \\
\text { researcher's survey to answer } \\
\text { this question on over } 220,000 \\
\text { individual patient visits over } \\
24 \text { months. We find that } \\
\text { patients are grateful for } \\
\text { hospital advertising; by } \\
\text { watching a TV commercial } \\
\text { for a certain hospital, a } \\
\text { patient's choice of hospital is } \\
\text { more likely. }\end{array}$ & $\begin{array}{l}\text { The reputation } \\
\text { of hospitals } \\
\text { leads patients to } \\
\text { hospitals of a } \\
\text { higher quality, } \\
\text { which have } \\
\text { more coverage } \\
\text { and lower } \\
\text { readmission } \\
\text { rates. }\end{array}$ & $\begin{array}{l}\text { Depending on insurance status, } \\
\text { medical conditions and } \\
\text { demographic factors including } \\
\text { age, gender and race, the study } \\
\text { researchers ' findings note } \\
\text { substantial variation in patient } \\
\text { response. Patients with more } \\
\text { strict insurance forms, for } \\
\text { example, are less susceptible to } \\
\text { advertising. }\end{array}$ & $\begin{array}{l}\text { The study } \\
\text { suggests that the } \\
\text { response to } \\
\text { patients be more } \\
\text { significant, based } \\
\text { on insurance } \\
\text { status, medical } \\
\text { conditions and } \\
\text { demographic } \\
\text { variables such as } \\
\text { age, gender and } \\
\text { race. However, } \\
\text { the overall } \\
\text { mortality rate is } \\
\text { not substantially } \\
\text { changed. }\end{array}$ \\
\hline
\end{tabular}




\section{DOI: $\underline{10.51386 / 25815946 / \text { ijsms-v4i3p113 }}$}

Volume: 4 Issue: 3

\begin{tabular}{|c|c|c|c|c|c|c|}
\hline 12. & $\begin{array}{c}\text { John H. Roberts } \\
(2019)\end{array}$ & $\begin{array}{c}\text { The objective of this study } \\
\text { is to analyze in Australia } \\
\text { the effect, both on primary } \\
\text { and secondary demand, of } \\
\text { legislation mandating plain } \\
\text { cigarette packaging in } \\
2012 .\end{array}$ & $\begin{array}{l}\text { The study conducted a } \\
\text { survey to analyze the causal } \\
\text { impact of cigarette category } \\
\text { legislation in comparison } \\
\text { with sales changes in the } \\
\text { comparable markets in New } \\
\text { Zealand, before and after } \\
\text { legislation, where no single } \\
\text { labeling requirement was } \\
\text { established, and the } \\
\text { subsequent sales changes. } \\
\text { Our figures indicate a } \\
\text { decrease in PPM sales of } \\
\text { around } 7,5 \text { percent of the } \\
\text { market by about } 67 \text { million } \\
\text { units (sticks) a month. }\end{array}$ & $\begin{array}{c}\text { The price } \\
\text { sensitivity of } \\
\text { the Premium } \\
\text { and traditional } \\
\text { brands after } \\
\text { PPM is most } \\
\text { affected, but we } \\
\text { also note } \\
\text { variations } \\
\text { between } \\
\text { channels and } \\
\text { foodstuffs } \\
\text { channels that } \\
\text { suggest that } \\
\text { short-term price } \\
\text { sensitivity after } \\
\text { PPM decreases } \\
\text { (declines). }\end{array}$ & $\begin{array}{c}\text { The findings of the study } \\
\text { suggest that PPM sales have } \\
\text { decreased by approximately } 67 \\
\text { million units a month, } \\
\text { representing approximately } \\
7.5 \% \text { of the market. The system } \\
\text { findings using brand-level sales } \\
\text { data from Australia indicate } \\
\text { lower price sensitivity after the } \\
\text { PPM. }\end{array}$ & $\begin{array}{l}\text { The John H. } \\
\text { Roberts report } \\
\text { provided the } \\
\text { Australian } \\
\text { government with } \\
\text { practical advice } \\
\text { on the probable } \\
\text { efficacy of the } \\
\text { one-off packaging } \\
\text { measure. He did } \\
\text { not specifically } \\
\text { test the templates } \\
\text { in this document } \\
\text { and at the } \\
\text { beginning of the } \\
\text { review process the } \\
\text { editor had been } \\
\text { told of this } \\
\text { situation. The } \\
\text { study also } \\
\text { recommended that } \\
\text { we look deeper at } \\
\text { the other } \\
\text { implications of } \\
\text { public policy of } \\
\text { our findings, such } \\
\text { as the predicted } \\
\text { revenue decrease } \\
\text { in New Zealand } \\
\text { each month due to } \\
\text { the establishment } \\
\text { of PPM. }\end{array}$ \\
\hline 13. & $\begin{array}{c}\text { Andrew G. } \\
\text { Parsons } \\
(2016)\end{array}$ & $\begin{array}{c}\text { The study aims to assess } \\
\text { the quality of shopping } \\
\text { mall offers: consumer } \\
\text { review }\end{array}$ & $\begin{array}{l}\text { The research looked at the } \\
\text { possibility of promoting } \\
\text { improvements in the two } \\
\text { main success metrics used by } \\
\text { shopping center marketers - } \\
\text { both sales and visitors. A } \\
\text { number of customers was } \\
\text { included in the survey. }\end{array}$ & $\begin{array}{l}\text { purchases, } \\
\text { visits, and } \\
\text { promotional } \\
\text { forms were } \\
\text { reviewed to } \\
\text { determine to } \\
\text { what extent the } \\
\text { actions of } \\
\text { consumers } \\
\text { matched the } \\
\text { reported } \\
\text { potential for } \\
\text { behaviour. }\end{array}$ & $\begin{array}{l}\text { The results indicate clear } \\
\text { differences between sellers and } \\
\text { consumer and indicate possible } \\
\text { combinations that would } \\
\text { produce optimum customer } \\
\text { comportment. }\end{array}$ & $\begin{array}{l}\text { The study } \\
\text { recommends } \\
\text { Some } \\
\text { conventional } \\
\text { promotions. }\end{array}$ \\
\hline 14. & $\begin{array}{c}\text { June Soo Lee } \\
\text { (2019) }\end{array}$ & $\begin{array}{l}\text { The goal of the study is to } \\
\text { assess the dynamic } \\
\text { effectiveness of a CPG } \\
\text { brand in a staple product } \\
\text { category cross media } \\
\text { publicity campaign in } \\
\text { China }\end{array}$ & $\begin{array}{l}\text { The research utilizes a survey } \\
\text { approach to evaluate single- } \\
\text { source data used in a cross- } \\
\text { media advertisement } \\
\text { campaign in a mature, staple } \\
\text { commodity category for a } \\
\text { leading CPG brand in China. } \\
\text { Data have been supplied in } \\
\text { Asia by a major worldwide } \\
\text { media company. Further } \\
\text { brand and segment } \\
\text { information cannot be } \\
\text { published because of } \\
\text { confidentiality agreements. }\end{array}$ & $\begin{array}{l}\text { The complex } \\
\text { effect of } \\
\text { publicity over } \\
\text { the acquisition } \\
\text { cycle, cross- } \\
\text { media synergies } \\
\text { and regional } \\
\text { improvements } \\
\text { in publicity } \\
\text { efficiency. }\end{array}$ & $\begin{array}{l}\text { The results of the study offer } \\
\text { new insights into the dynamics } \\
\text { and asymmetries of cross- } \\
\text { media impact at individual } \\
\text { levels and add critically to a } \\
\text { limited number of evidences on } \\
\text { this topic. In addition, the } \\
\text { findings on regional variations } \\
\text { in publicity responses offer an } \\
\text { important but under-examined } \\
\text { view from China. Contrary to } \\
\text { recent research suggesting that } \\
\text { on-line TV synergies have at } \\
\text { best tenuous effects in market. }\end{array}$ & $\begin{array}{c}\text { The report } \\
\text { suggested a } \\
\text { specific range of } \\
\text { studies dealing in } \\
\text { particular with the } \\
\text { effects of } \\
\text { intermediate } \\
\text { exposures at } \\
\text { individual level on } \\
\text { buying behaviour. }\end{array}$ \\
\hline 15. & $\begin{array}{c}\text { Wen-Hsiang } \\
\text { Lai } \\
(2016)\end{array}$ & $\begin{array}{l}\text { The purpose of the } \\
\text { research is to evaluate the } \\
\text { satisfaction of tourists } \\
\text { following a visit to } \\
\text { Vietnam, which has not }\end{array}$ & $\begin{array}{l}\text { This study provides an } \\
\text { insight into the } \\
\text { interrelationships between } \\
\text { promotional activities, visitor } \\
\text { perceptions, tourist }\end{array}$ & $\begin{array}{c}\text { Promotion } \\
\text { activities are } \\
\text { closely linked to } \\
\text { the tourist } \\
\text { preferences of }\end{array}$ & $\begin{array}{l}\text { The findings of this study may } \\
\text { allow tourism marketers to } \\
\text { align their marketing and } \\
\text { promotional activities with } \\
\text { effective destination }\end{array}$ & $\begin{array}{l}\text { This study shows } \\
\text { that the quality of } \\
\text { service, including } \\
\text { tourism goods and } \\
\text { service personnel, }\end{array}$ \\
\hline
\end{tabular}




\section{DOI: $\underline{10.51386 / 25815946 / \text { ijsms-v4i3p113 }}$}

Volume: 4 Issue: 3

\begin{tabular}{|c|c|c|c|c|c|c|}
\hline & & $\begin{array}{c}\text { demanded unique Vietnam } \\
\text { tourism sites such as } \\
\text { Hanoi, Halong Bay, Hue } \\
\text { City and Danang City. }\end{array}$ & $\begin{array}{l}\text { satisfaction and loyalty to } \\
\text { destinations. By employing } \\
\text { the SEM process, the } \\
\text { research has provided the } \\
\text { literature with empirical } \\
\text { support and tested six } \\
\text { hypotheses concerning } \\
\text { promotion and evaluation } \\
\text { factors which affect visitor } \\
\text { fidelity in Vietnam. }\end{array}$ & $\begin{array}{l}\text { the destination. } \\
\text { Advocacy is } \\
\text { positively } \\
\text { related to } \\
\text { overall } \\
\text { satisfaction of } \\
\text { destination. } \\
\text { Marketing is } \\
\text { strongly linked } \\
\text { to the } \\
\text { commitment to } \\
\text { the destination. }\end{array}$ & $\begin{array}{l}\text { management organizations. } \\
\text { Advertisement efforts are } \\
\text { important to raising tourist } \\
\text { destination confusion by } \\
\text { generating and meeting tourist } \\
\text { needs. Marketers can use } \\
\text { successful advertisement } \\
\text { strategies to manipulate } \\
\text { customer preferences because } \\
\text { they understand the way } \\
\text { consumers are looking for } \\
\text { information (McColl \& Fetter, } \\
\text { 1999). }\end{array}$ & $\begin{array}{l}\text { must be enhanced } \\
\text { in order to achieve } \\
\text { a higher overall } \\
\text { level of } \\
\text { satisfaction and to } \\
\text { increase the } \\
\text { overall destination } \\
\text { brand and loyalty } \\
\text { to tourists. }\end{array}$ \\
\hline 16. & $\begin{array}{l}\text { H-H Yong, } \\
\text { Borland, \& D } \\
\text { Hammond } \\
\text { (2017) }\end{array}$ & $\begin{array}{l}\text { The purpose of this survey } \\
\text { is to research the effect of } \\
\text { tobacco advertising in two } \\
\text { developing countries, } \\
\text { Malaysia and Thailand, on } \\
\text { adult smokers ' awareness } \\
\text { about the promotion of } \\
\text { tobacco. }\end{array}$ & $\begin{array}{l}\text { The researcher used a survey } \\
\text { of the findings of the } \\
\text { international survey of } \\
\text { Tobacco Control South Asia } \\
\text { (ITC-SEA) conducted by } \\
\text { Malaysia's and } 2000 \text { Thai } \\
\text { adult smokers. Respondents } \\
\text { were asked to demonstrate } \\
\text { their knowledge of tobacco } \\
\text { advertisements and } \\
\text { promotional practices over } \\
\text { the last six months in a } \\
\text { person-to-person interview } \\
\text { between January and March } \\
\text { 2005. }\end{array}$ & $\begin{array}{l}\text { The levels of } \\
\text { perception and } \\
\text { associations of } \\
\text { the promotion } \\
\text { of tobacco. } \\
\text { Adult smokers } \\
\text { in Thailand and } \\
\text { Malaysia }\end{array}$ & $\begin{array}{l}\text { The study revealed a very low } \\
\text { ( } 20 \text { percent) but substantially } \\
\text { higher consciousness in } \\
\text { Malaysia of some tobacco } \\
\text { marketing practices (53 } \\
\text { percent; OR = 5.6; } 95 \text { percent } \\
\text { of CI: } 3.5-8.9 \text { and p <0.001). } \\
\text { Thai adult smokers report very } \\
\text { low recall of cigarette ads } \\
\text { where it was prohibited when } \\
\text { asked to specific locations, with } \\
\text { sales outlets being among the } \\
\text { lowest, in particular street } \\
\text { vendors }(7.5 \%) \text {. }\end{array}$ & $\begin{array}{l}\text { The } \\
\text { recommendation } \\
\text { of the study } \\
\text { indicates that } \\
\text { rigorous } \\
\text { regulations on } \\
\text { tobacco ads when } \\
\text { properly applied } \\
\text { will result in a } \\
\text { drastic reduction } \\
\text { in the } \\
\text { consciousness } \\
\text { about the } \\
\text { promotion of } \\
\text { tobacco. }\end{array}$ \\
\hline 17. & $\begin{array}{c}\text { S Anderson } \\
\text { (2016) }\end{array}$ & $\begin{array}{l}\text { The goal of the study is to } \\
\text { analyze the impact on UK } \\
\text { adult tobacco marketing } \\
\text { perception of Canada, the } \\
\text { United States and Australia } \\
\text { of the full UK ban on } \\
\text { tobacco advertising. }\end{array}$ & $\begin{array}{l}\text { A cumulative sample of } 6762 \\
\text { adult smokers in the four } \\
\text { countries engaged in two } \\
\text { waves of a random digitally- } \\
\text { digited telephone survey. }\end{array}$ & $\begin{array}{l}\text { Politicians } \\
\text { responded by } \\
\text { implementing } \\
\text { legislative } \\
\text { measures to } \\
\text { regulate } \\
\text { advertisement } \\
\text { and promotional } \\
\text { practices in the } \\
\text { industry to the } \\
\text { public health } \\
\text { danger raised by } \\
\text { tobacco } \\
\text { marketing }\end{array}$ & $\begin{array}{l}\text { In the first place, the findings } \\
\text { of this research explore how } \\
\text { participants in the four } \\
\text { countries varied in their } \\
\text { knowledge of tobacco } \\
\text { marketing at baseline and over } \\
\text { time and how this related to } \\
\text { regulatory rates in each } \\
\text { country. Secondly, the findings } \\
\text { deal with the effect on } \\
\text { perception of the UK ban and, } \\
\text { thirdly, if the UK prohibition } \\
\text { resulted in a change to non } \\
\text { interrupted channels. }\end{array}$ & $\begin{array}{l}\text { The report } \\
\text { concluded that the } \\
\text { UK's strategy of } \\
\text { banning the } \\
\text { advertising and } \\
\text { promotion of } \\
\text { cigarettes } \\
\text { significantly } \\
\text { lowered the } \\
\text { exposure to } \\
\text { pressures on the } \\
\text { market. This } \\
\text { finding also } \\
\text { supports the } \\
\text { successful } \\
\text { adoption, as part } \\
\text { of the Framework } \\
\text { Convention on } \\
\text { Tobacco Control, } \\
\text { of extensive } \\
\text { advertising and } \\
\text { promotion bans. }\end{array}$ \\
\hline
\end{tabular}




\section{DOI: $\underline{10.51386 / 25815946 / \text { ijsms-v4i3p113 }}$}

Volume: 4 Issue: 3

\begin{tabular}{|c|c|c|c|c|c|c|}
\hline 18. & $\begin{array}{c}\text { V. Kumar \& } \\
\text { Robert P. Leone } \\
\text { (2016) }\end{array}$ & $\begin{array}{l}\text { The work aims to } \\
\text { investigate the impact on } \\
\text { the selling of marks of } \\
\text { disposable clothes in the } \\
\text { city of price advertising, } \\
\text { features and displays. }\end{array}$ & $\begin{array}{c}\text { In order to identify the } \\
\text { competitive structure of retail } \\
\text { shops within a test market } \\
\text { city, the investigator used a } \\
\text { hierarchical, cross-section } \\
\text { and time series modelling } \\
\text { procedure. }\end{array}$ & $\begin{array}{l}\text { In particular, } \\
\text { promotions are } \\
\text { significant and } \\
\text { the magnitude } \\
\text { of the effect } \\
\text { depends on the } \\
\text { geographical } \\
\text { proximity of the } \\
\text { shops. }\end{array}$ & $\begin{array}{l}\text { The results from the internal } \\
\text { substitution models were } \\
\text { focused on the definition of } \\
\text { these models. Pricing was the } \\
\text { highest level of brand } \\
\text { substitution in a store, followed } \\
\text { by displays and features. } \\
\text { Similarly, in some instances, } \\
\text { these practices provided shop } \\
\text { replacements. }\end{array}$ & $\begin{array}{l}\text { In some } \\
\text { situations, the } \\
\text { study proposed } \\
\text { initiatives to } \\
\text { replace the shop. } \\
\text { Such unique } \\
\text { advertising } \\
\text { variables are also } \\
\text { important and the } \\
\text { magnitude of the } \\
\text { effect on the } \\
\text { future role of } \\
\text { shops ' } \\
\text { geographical } \\
\text { proximity. }\end{array}$ \\
\hline 19. & $\begin{array}{l}\text { Rockney G. } \\
\text { Walters } \\
\text { (2016) }\end{array}$ & $\begin{array}{l}\text { The goal of the study is to } \\
\text { examine the effect of retail } \\
\text { price advocates and the } \\
\text { performance of competing } \\
\text { retailers on consumer } \\
\text { buying patterns. }\end{array}$ & $\begin{array}{l}\text { In the study, the system was } \\
\text { examined by scanner data } \\
\text { from the store level. Results } \\
\text { support the system broadly } \\
\text { and show that retail price } \\
\text { promotions have produced } \\
\text { important complementary } \\
\text { and replacement effects } \\
\text { within the company. In some } \\
\text { cases, Interstore promotional } \\
\text { effects were also found as the } \\
\text { sales of replacements and } \\
\text { supplements decreased } \\
\text { significantly in the } \\
\text { competition store in one of } \\
\text { its products' promotions. }\end{array}$ & $\begin{array}{l}\text { A promotional } \\
\text { variable is } \\
\text { created that } \\
\text { involves brand } \\
\text { substitution } \\
\text { effects, } \\
\text { Interstore sales } \\
\text { displacements } \\
\text { and promotions } \\
\text { ' effects on } \\
\text { complementary } \\
\text { products. }\end{array}$ & $\begin{array}{l}\text { The findings generally support } \\
\text { the structure and show that } \\
\text { retail price discounts have } \\
\text { produced substantial additional } \\
\text { and replacement effects. And in } \\
\text { many cases the marketing of } \\
\text { goods in a single store } \\
\text { decreased significantly sales of } \\
\text { replacement and complements } \\
\text { in a rival store. Interstore } \\
\text { promotional impacts were } \\
\text { detected. Implications of the } \\
\text { results are addressed for retail } \\
\text { and supplier promotional } \\
\text { activities and a range of } \\
\text { directions are given for future } \\
\text { research. }\end{array}$ & $\begin{array}{l}\text { The study } \\
\text { proposed product } \\
\text { promotions and } \\
\text { recommendations } \\
\text { for future } \\
\text { research. }\end{array}$ \\
\hline 20. & $\begin{array}{c}\text { Roger B. Mason } \\
\text { (2018) }\end{array}$ & $\begin{array}{l}\text { The aim of this paper is to } \\
\text { explore word for words } \\
\text { from the point of view of } \\
\text { chaos/complexity theory. }\end{array}$ & $\begin{array}{l}\text { This research used the survey } \\
\text { the value of word of mouth } \\
\text { in competitive markets is } \\
\text { analyzed using a multiple } \\
\text { case study methodology. } \\
\text { Most successful businesses } \\
\text { were found to proactively use } \\
\text { word of mouth and are an } \\
\text { effective marketing tool for } \\
\text { challenging environments. }\end{array}$ & $\begin{array}{c}\text { The active } \\
\text { nature of the } \\
\text { first conditions } \\
\text { (the butterfly } \\
\text { effect) is a } \\
\text { central feature } \\
\text { of the theory of } \\
\text { chaos. }\end{array}$ & $\begin{array}{l}\text { The findings of this paper are } \\
\text { significant because the } \\
\text { academic community has not } \\
\text { paid much attention to word of } \\
\text { mouth, except for electronic } \\
\text { terms. }\end{array}$ & $\begin{array}{l}\text { The proposal for } \\
\text { the study } \\
\text { represents a } \\
\text { theoretical theory } \\
\text { that has not been } \\
\text { discussed } \\
\text { previously. } \\
\text { Therefore, it is } \\
\text { necessary, since } \\
\text { word of mouth is } \\
\text { vital for marketing } \\
\text { in less } \\
\text { sophisticated or } \\
\text { literate markets in } \\
\text { South Africa and } \\
\text { probably in other } \\
\text { underdeveloped } \\
\text { and developing } \\
\text { countries. }\end{array}$ \\
\hline 21. & $\begin{array}{c}\text { Lisa T. Fall } \\
\text { PhD } \\
(2018)\end{array}$ & $\begin{array}{l}\text { This paper is intended to } \\
\text { demonstrate that the } \\
\text { advertising and } \\
\text { promotional schemes } \\
\text { introduced by top } \\
\text { government tourism } \\
\text { expenders in the United } \\
\text { States have a financial } \\
\text { value. }\end{array}$ & $\begin{array}{l}\text { The study used a sample of a } \\
\text { three-section survey. Firstly, } \\
\text { there are debates on the } \\
\text { overall economic impact of } \\
\text { the tourism, hospitality and } \\
\text { transport industry (TT\&H). } \\
\text { Secondly, various methods } \\
\text { for assessing and analyzing } \\
\text { promotional practices in the } \\
\text { field of public relations are } \\
\text { evaluated for this specific }\end{array}$ & $\begin{array}{l}\text { The various } \\
\text { methods used } \\
\text { by the } \\
\text { researcher in } \\
\text { this field to } \\
\text { analyze and } \\
\text { quantify } \\
\text { promotional } \\
\text { public relations } \\
\text { activities are } \\
\text { measured the }\end{array}$ & $\begin{array}{l}\text { The results of the study show } \\
\text { that value communication gains } \\
\text { are verified and that the } \\
\text { countries under investigation } \\
\text { have achieved a healthy return } \\
\text { on their promotion efforts in } \\
\text { three economic aspects: return } \\
\text { on investment ratio, income per } \\
\text { person produced and cost per } \\
\text { person. }\end{array}$ & $\begin{array}{l}\text { The research } \\
\text { recommended the } \\
\text { results of the } \\
\text { return on } \\
\text { investment ratio, } \\
\text { the revenue } \\
\text { produced by } \\
\text { individuals and } \\
\text { management costs } \\
\text { per person and } \\
\text { suggested for }\end{array}$ \\
\hline
\end{tabular}




\section{DOI: $\underline{10.51386 / 25815946 / \text { ijsms-v4i3p113 }}$}

Volume: 4 Issue: 3

May to June 2021

www.ijsmsjournal.org

\begin{tabular}{|c|c|c|c|c|c|c|}
\hline & & & $\begin{array}{l}\text { industry. And, third, the cost- } \\
\text { effectiveness of leisure } \\
\text { campaign marketing } \\
\text { activities is measured in each } \\
\text { country's expenditure-to- } \\
\text { income figures. }\end{array}$ & $\begin{array}{l}\text { cost-to-revenue } \\
\text { statistic of the } \\
\text { individual states } \\
\text { is determined in } \\
\text { order to } \\
\text { ascertain the } \\
\text { cost- } \\
\text { effectiveness of } \\
\text { tourism } \\
\text { campaign } \\
\text { promotion } \\
\text { efforts. }\end{array}$ & & future studies. \\
\hline 22. & $\begin{array}{l}\text { Anindya Ghose, } \\
\text { Panagiotis G. } \\
\text { Ipeirotis, \& } \\
\text { Beibei Li } \\
\text { (2017) }\end{array}$ & $\begin{array}{l}\text { In response to the customer } \\
\text { queries, the aim of this } \\
\text { research is to enhance } \\
\text { products which provide } \\
\text { higher surpluses. }\end{array}$ & $\begin{array}{l}\text { The study employed the } \\
\text { analysis of a unique data } \\
\text { package of U.S. hotel } \\
\text { reservations for a three- } \\
\text { month period via } \\
\text { Travelocity, which we use } \\
\text { text mining, image } \\
\text { recognition, social } \\
\text { geotagging and descriptions } \\
\text { of human beings and } \\
\text { gemmating to complement } \\
\text { with data from various media } \\
\text { sources. }\end{array}$ & $\begin{array}{l}\text { Therefore, the } \\
\text { researcher } \\
\text { emphasizes the } \\
\text { close relation } \\
\text { between social } \\
\text { media user } \\
\text { activity and } \\
\text { search engines. }\end{array}$ & $\begin{array}{l}\text { The findings of the research } \\
\text { suggest a new system of hotel } \\
\text { rankings based on the average } \\
\text { benefit earned by a customer in } \\
\text { a certain hotel. By this way we } \\
\text { will bring the "best value" } \\
\text { hotels to customers very early. } \\
\text { Our usage tests confirm the } \\
\text { superiority of our ranking } \\
\text { method over our current } \\
\text { systems with many travel } \\
\text { search engines using ranking } \\
\text { comparisons. }\end{array}$ & $\begin{array}{l}\text { In order to } \\
\text { achieve the best } \\
\text { value for money, } \\
\text { the researcher } \\
\text { advocates and } \\
\text { supports the } \\
\text { creation of a } \\
\text { grading system } \\
\text { evaluating goods. } \\
\text { A new system of } \\
\text { hotel rankings } \\
\text { based on average } \\
\text { customer benefits } \\
\text { earned from a } \\
\text { certain hotel was } \\
\text { suggested in the } \\
\text { report. This helps } \\
\text { us to offer the } \\
\text { "best value" hotels } \\
\text { to customers } \\
\text { early. }\end{array}$ \\
\hline 23. & $\begin{array}{c}\text { Chu- Mei Liu } \\
\text { (2019) }\end{array}$ & $\begin{array}{l}\text { The research aims to } \\
\text { examine the impacts on } \\
\text { consumer choice between } \\
\text { mobile phone brands of the } \\
\text { different activities. }\end{array}$ & $\begin{array}{l}\text { A survey conducted by the } \\
\text { investigator included a total } \\
\text { of } 800 \text { participants. The } \\
\text { results of the step-by-step } \\
\text { regression analysis suggest } \\
\text { that during the third iteration, } \\
\text { but moved during the next } \\
\text { iteration stage, the initial } \\
\text { impact of service provider } \\
\text { advertising was felt. }\end{array}$ & $\begin{array}{c}\text { Mobile } \\
\text { subscriptions in } \\
\text { the Philippines } \\
\text { are increasing } \\
\text { considerably } \\
\text { more rapidly. } \\
\text { Cooperation } \\
\text { between service } \\
\text { providers and } \\
\text { mobile } \\
\text { telephone firms } \\
\text { is a form of } \\
\text { advertising and } \\
\text { promotion. }\end{array}$ & $\begin{array}{l}\text { The results of the step-by-step } \\
\text { regression analysis show the } \\
\text { initial impact of service } \\
\text { provider advertising during the } \\
\text { third iteration, but moved } \\
\text { during the next iteration stage. }\end{array}$ & $\begin{array}{l}\text { The study } \\
\text { suggested that the } \\
\text { variable-choice } \\
\text { relationship is } \\
\text { important with } \\
\text { price upward } \\
\text { variance alone and } \\
\text { the present model } \\
\text { with an inverse } \\
\text { relationship and } \\
\text { the brand } \\
\text { definition with the } \\
\text { highest positive } \\
\text { impact. }\end{array}$ \\
\hline
\end{tabular}




\section{DOI: $\underline{10.51386 / 25815946 / \text { ijsms-v4i3p113 }}$}

Volume: 4 Issue: 3

\begin{tabular}{|c|c|c|c|c|c|c|}
\hline 24. & $\begin{array}{l}\text { Paul Whitla } \\
\text { (2019) }\end{array}$ & $\begin{array}{l}\text { This study explores how } \\
\text { businesses use } \\
\text { crowdsourcing for } \\
\text { marketing activities, } \\
\text { focusing on three specific } \\
\text { product, advertising and } \\
\text { promotion and marketing } \\
\text { research areas. This } \\
\text { research would concentrate } \\
\text { on marketing activities. }\end{array}$ & $\begin{array}{l}\text { The work carried out a } \\
\text { mission that was assigned } \\
\text { and paid for its efforts. While } \\
\text { this type of labor } \\
\text { organization was a pioneer in } \\
\text { the computer industry, } \\
\text { corporations started to use } \\
\text { "crowdsourcing" for different } \\
\text { tasks that the representatives } \\
\text { of a crowd rather than their } \\
\text { employees could do } \\
\text { something about. }\end{array}$ & $\begin{array}{c}\text { Companies use } \\
\text { crowdsourcing } \\
\text { to complete } \\
\text { marketing tasks, } \\
\text { focusing on } \\
\text { three specific } \\
\text { product areas } \\
\text { deCrossdsourci } \\
\text { ng is a newly } \\
\text { developed term } \\
\text { which refers to } \\
\text { an online } \\
\text { community and } \\
\text { crowd } \\
\text { outsourcing } \\
\text { process in the } \\
\text { form of an' open } \\
\text { call. }\end{array}$ & $\begin{array}{l}\text { The study has shown that some } \\
\text { organizations use } \\
\text { crowdsourcing to identify } \\
\text { several people who are willing } \\
\text { to perform mostly small, } \\
\text { recurring tasks for minimal } \\
\text { financial compensation. }\end{array}$ & $\begin{array}{l}\text { The study } \\
\text { suggests the } \\
\text { benefits and } \\
\text { disadvantages of } \\
\text { crowdsourcing } \\
\text { and the ability to } \\
\text { future use of } \\
\text { crowdsourcing in } \\
\text { additional } \\
\text { marketing } \\
\text { applications. }\end{array}$ \\
\hline 25. & $\begin{array}{c}\text { Monika Arora } \\
\text { \& Neha Mathur } \\
\text { (2017) }\end{array}$ & $\begin{array}{l}\text { This work aims to analyze } \\
\text { the risk factor in } \\
\text { Hollywood films for teen } \\
\text { smoking in the USA and } \\
\text { Europe as well as to the } \\
\text { correlation of exposure to } \\
\text { tobacco use in Bollywood } \\
\text { films with the use of teen } \\
\text { smoking in India. The goal } \\
\text { is to research this risk } \\
\text { factor. }\end{array}$ & $\begin{array}{l}\text { In the study, } 3956 \text { teenagers } \\
\text { (12 to } 12 \text { years of age) from } \\
12 \text { randomly selected schools } \\
\text { in New Delhi (eighth and } \\
\text { ninth grades) were surveyed } \\
\text { in } 2009 \text {, assessing the status } \\
\text { of the tobacco usage, obtain } \\
\text { promotion of tobacco (based } \\
\text { on owning or ready to wear } \\
\text { tobacco-branded goods) and } \\
\text { the exposure to the use of } \\
\text { tobacco in film. }\end{array}$ & $\begin{array}{c}\text { Tobacco- } \\
\text { evaluation } \\
\text { status variables, } \\
\text { tobacco } \\
\text { advertisement } \\
\text { receptivity } \\
\text { (based on } \\
\text { possession or } \\
\text { ability to wear } \\
\text { tobacco } \\
\text { products) and } \\
\text { tobacco use } \\
\text { access to } \\
\text { movies. }\end{array}$ & $\begin{array}{l}\text { The result was } 412 \text { instances of } \\
\text { tobacco in the } 59 \text { films. The } \\
\text { number of adolescents using } \\
\text { tobacco was } 5.3 \% \text {. The adapted } \\
\text { odds of ever-tobacco } \\
\text { consumption among high- } \\
\text { exposure adolescents (quartile } \\
\text { 4) was } 2.3 \text { ( } 95 \text { percent CI } 1.3 \text { to } \\
\text { 3.9) compared with low- } \\
\text { exposure adolescents (quartile } \\
\text { 1). Tobacco receptiveness was } \\
\text { also linked to higher adjusted } \\
\text { oddities of tobacco use, } 2.0 \text { (CI } \\
1.4 \text { to } 3.095 \% \text { ). }\end{array}$ & $\begin{array}{l}\text { The study } \\
\text { proposes that } \\
\text { watching the use } \\
\text { of tobacco in } \\
\text { Bollywood films } \\
\text { and tobacco } \\
\text { promotional } \\
\text { receptivity were } \\
\text { both independent } \\
\text { of adolescents in } \\
\text { India, while ORs } \\
\text { are similar to } \\
\text { adolescents in } \\
\text { other countries. }\end{array}$ \\
\hline 26. & $\begin{array}{c}\text { Aradhna } \\
\text { Krishna, Robert } \\
\text { W. Shoemaker } \\
\text { \& Imran S. } \\
\text { Currim } \\
\text { (2018) }\end{array}$ & $\begin{array}{l}\text { The investigator explores } \\
\text { various aspects of } \\
\text { customer expectations of } \\
\text { deal duration and deal size. }\end{array}$ & $\begin{array}{l}\text { In order to estimate the } \\
\text { degree of consumer } \\
\text { information on selling } \\
\text { frequency and deal costs, the } \\
\text { study has used an exanimated } \\
\text { result of a comprehensive } \\
\text { survey. Although the } \\
\text { expected frequency of } \\
\text { dealings and the expected } \\
\text { price of a deal for a customer } \\
\text { decision are relevant, there } \\
\text { has been relatively little } \\
\text { empirical research on these } \\
\text { subjects. }\end{array}$ & $\begin{array}{l}\text { The frequency } \\
\text { and deal price } \\
\text { understanding } \\
\text { of customers as } \\
\text { to how } \\
\text { consumers build } \\
\text { and use these } \\
\text { perceptions. }\end{array}$ & $\begin{array}{l}\text { The results show that other } \\
\text { consumers are similarly correct } \\
\text { in terms of the number of sales } \\
\text { and sale prices. Furthermore, } \\
\text { noting the level of transactions } \\
\text { and selling prices is higher for } \\
\text { buyers of larger families and } \\
\text { who read fliers on weekly } \\
\text { basis, spend a greater } \\
\text { proportion of their product } \\
\text { class purchases and more } \\
\text { regularly buy the package. For } \\
\text { older purchasers, it is lower. }\end{array}$ & $\begin{array}{l}\text { This study } \\
\text { suggests that } \\
\text { several customer } \\
\text { reactions models } \\
\text { for promotions } \\
\text { display a brand } \\
\text { and purchase } \\
\text { quantity decision } \\
\text { based on the } \\
\text { expected time to } \\
\text { the next price } \\
\text { reduction and the } \\
\text { expected size of } \\
\text { possible } \\
\text { reductions. }\end{array}$ \\
\hline 27. & $\begin{array}{c}\text { Tilman A. } \\
\text { Schenk, Günter } \\
\text { Löffler \& } \\
\text { Jürgen Rauh } \\
\text { (2016) }\end{array}$ & $\begin{array}{l}\text { The purpose of this } \\
\text { research is to explore how } \\
\text { technical solutions model } \\
\text { space choice on a regional } \\
\text { level are relevant to } \\
\text { shopping behaviour. }\end{array}$ & $\begin{array}{l}\text { This research analyzed an } \\
\text { individual population based } \\
\text { micro-model agent for } \\
\text { grocery shopping based on } \\
\text { data collected in the north of } \\
\text { Sweden. }\end{array}$ & $\begin{array}{l}\text { The ability to } \\
\text { micro-scale } \\
\text { simulation of } \\
\text { human actions. }\end{array}$ & $\begin{array}{l}\text { The study shows that the high } \\
\text { quality of the data obtained } \\
\text { specifically for this reason } \\
\text { makes it possible to properly } \\
\text { test the simulation results. }\end{array}$ & $\begin{array}{l}\text { The study } \\
\text { recommended that } \\
\text { future applications } \\
\text { include the } \\
\text { forecast for } \\
\text { consumer } \\
\text { behavior and } \\
\text { turnover } \\
\text { predictions on the } \\
\text { basis of which } \\
\text { supply } \\
\text { adjustments may } \\
\text { be made, } \\
\text { particularly with } \\
\text { regard to } \\
\text { competition }\end{array}$ \\
\hline
\end{tabular}




\section{DOI: $\underline{10.51386 / 25815946 / \text { ijsms-v4i3p113 }}$}

Volume: 4 Issue: 3

\begin{tabular}{|c|c|c|c|c|c|c|}
\hline & & & & & & $\begin{array}{l}\text { between the center } \\
\text { shops and the } \\
\text { city's periphery. }\end{array}$ \\
\hline 28. & $\begin{array}{c}\text { Johanna } \\
\text { Kuenzel and } \\
\text { Pieter Musters } \\
\text { (2016) }\end{array}$ & $\begin{array}{l}\text { The aim of these items is } \\
\text { to find out if they all } \\
\text { participate poorly (as } \\
\text { previously assumed), and } \\
\text { if social influence } \\
\text { contributes to the buying } \\
\text { decision. }\end{array}$ & $\begin{array}{l}\text { The researchers used a test } \\
\text { that exposed variations in the } \\
\text { responsiveness to insightful } \\
\text { social impact and in the scale } \\
\text { of different networks. All } \\
\text { results impact the modelling: } \\
\text { Firstly, the commodity must } \\
\text { be taken into account when } \\
\text { modeling the interactions } \\
\text { between consumers. }\end{array}$ & $\begin{array}{l}\text { This study } \\
\text { focuses on } \\
\text { social } \\
\text { interaction in a } \\
\text { specific field: } \\
\text { everyday foods. }\end{array}$ & $\begin{array}{l}\text { The study found that the } \\
\text { presence of various foodstuffs } \\
\text { varies significantly. }\end{array}$ & $\begin{array}{l}\text { The study } \\
\text { recommends more } \\
\text { work on product } \\
\text { visibility. }\end{array}$ \\
\hline 29. & $\begin{array}{c}\text { Wander Jager } \\
(2017)\end{array}$ & $\begin{array}{l}\text { This work aims to explore } \\
\text { the creation of a social } \\
\text { simulation model for } \\
\text { consumer markets and to } \\
\text { make a formalization of } \\
\text { the four P's. }\end{array}$ & $\begin{array}{l}\text { The research used to conduct } \\
\text { a survey on the creation and } \\
\text { use of different types of } \\
\text { empirical data for an } \\
\text { experimental design based on } \\
\text { that formalization. }\end{array}$ & $\begin{array}{l}\text { In order to } \\
\text { optimize the } \\
\text { success of their } \\
\text { products on the } \\
\text { market, the } \\
\text { commodity, } \\
\text { size, placement } \\
\text { and promotion. }\end{array}$ & $\begin{array}{l}\text { The results of this study } \\
\text { indicate that marketing } \\
\text { researchers and practices can } \\
\text { gain an understanding of how } \\
\text { the four Ps apply to market } \\
\text { dynamics and how marketers } \\
\text { can use them for competitive } \\
\text { market management. }\end{array}$ & $\begin{array}{l}\text { This research } \\
\text { recommends the } \\
\text { creation and use } \\
\text { of different types } \\
\text { of empirical data } \\
\text { for marketing } \\
\text { purposes to } \\
\text { encourage and } \\
\text { improve } \\
\text { understanding of } \\
\text { these four P's in } \\
\text { experimental } \\
\text { design based on } \\
\text { such } \\
\text { formalization. }\end{array}$ \\
\hline 30. & $\begin{array}{l}\text { Segismundo S. } \\
\text { Izquierdo } \\
(2017)\end{array}$ & $\begin{array}{l}\text { This research is to assess } \\
\text { price volatility and } \\
\text { uncertainty market effects } \\
\text { without asymmetric } \\
\text { business efficiency } \\
\text { knowledge }\end{array}$ & $\begin{array}{l}\text { This research used an agent- } \\
\text { based model to show, even in } \\
\text { the absence of asymmetric } \\
\text { information's, how quality } \\
\text { uncertainties by themselves } \\
\text { can cause a market failure. }\end{array}$ & $\begin{array}{l}\text { The survey used } \\
\text { variables, } \\
\text { contextual } \\
\text { variation as an } \\
\text { independent } \\
\text { variable, while } \\
\text { business } \\
\text { performance } \\
\text { volatility is the } \\
\text { reliable } \\
\text { variable. }\end{array}$ & $\begin{array}{l}\text { The research shows that } \\
\text { consumers measure product } \\
\text { quality on the basis of their } \\
\text { previous transactions and } \\
\text { taking into account personally } \\
\text { responsive and objective } \\
\text { quality evaluation rules, this } \\
\text { study shows that consumer } \\
\text { engagement with quality } \\
\text { insecurity usually leads to } \\
\text { underestimations both of } \\
\text { product quality and systemic } \\
\text { price reductions and losses. }\end{array}$ & $\begin{array}{l}\text { This study has } \\
\text { suggested to } \\
\text { mitigate this } \\
\text { market failure } \\
\text { considerably by } \\
\text { disseminating } \\
\text { knowledge } \\
\text { through social } \\
\text { networks. }\end{array}$ \\
\hline 31 & $\begin{array}{l}\text { Todorova } \\
(2015)\end{array}$ & $\begin{array}{l}\text { The purpose of this report } \\
\text { is to present theoretical } \\
\text { concepts and developments } \\
\text { in the concept of " } \\
\text { marketing communication } \\
\text { mix" }\end{array}$ & $\begin{array}{l}\text { Successful marketing } \\
\text { communication relies on a } \\
\text { combination of tools called } \\
\text { the "promotional mix" }\end{array}$ & $\begin{array}{l}\text { Designing the } \\
\text { right marketing } \\
\text { mix involves } \\
\text { the four P's i.e. } \\
\text { Product, Price, } \\
\text { Place and } \\
\text { Promotion. In } \\
\text { the field of } \\
\text { marketing } \\
\text { communication }\end{array}$ & $\begin{array}{l}\text { tools include: Advertising, } \\
\text { Public relations, Sales } \\
\text { promotion, Direct marketing, } \\
\text { Personal selling, and are used } \\
\text { to describe the set of tools that } \\
\text { a business can use to } \\
\text { communicate effectively the } \\
\text { benefits of your products or } \\
\text { services to its customers. Key } \\
\text { words: Marketing } \\
\text { communications, }\end{array}$ & $\begin{array}{l}\text { Do more future } \\
\text { research }\end{array}$ \\
\hline
\end{tabular}


DOI: $\underline{10.51386 / 25815946 / \text { ijsms-v4i3p113 }}$

Volume: 4 Issue: 3

May to June 2021

www.ijsmsjournal.org

\begin{tabular}{|c|c|c|c|c|c|}
\hline 32 & Khanfar (2016) & $\begin{array}{c}\text { This research aims to study } \\
\text { the factors affecting the } \\
\text { consumers buying } \\
\text { decisions of mobile service } \\
\text { provided by Umniah } \\
\text { Telecommunications } \\
\text { Company in Zarqa city }\end{array}$ & $\begin{array}{c}\text { Data were collected through } \\
\text { questionnaires forming a } \\
\text { representative sample }\end{array}$ & $\begin{array}{c}\text { the factors } \\
\text { include } \\
\text { advertising, } \\
\text { personal } \\
\text { selling, sales } \\
\text { promotion, and } \\
\text { public relations }\end{array}$ & $\begin{array}{c}\text { the findings indicated that there } \\
\text { is a positive effect of } \\
\text { advertising, personal selling, } \\
\text { sales promotion, and public } \\
\text { relations with consumers } \\
\text { buying decisions. Advertising } \\
\text { was found to be the most } \\
\text { critical factor in affecting } \\
\text { consumers buying decisions } \\
\text { Umniah Company } \\
\text { should focus more } \\
\text { on sales } \\
\text { promotion in } \\
\text { order to satisfy } \\
\text { consumers more } \\
\text { as well as to } \\
\text { enhance their } \\
\text { buying decision. }\end{array}$ \\
\hline
\end{tabular}

\section{4: Research Gap analysis}

Although there are several studies on advertising, personal sales, direct marketing, promotion of a product, and public relations that were shown in the analysis above, many of these studies have been done in other contexts focusing on promotional activities and have only one or two vector indices such as income and market share of sales volumes, etc. Our study has been expanded to a new environment (Nigeria), and especially General Juice Plc. Five variables (advertising, personal sales, direct marketing, sales promotion, public relations). The aim is to see whether advertising, personal sales, direct marketing, promotions of sales, and public relations will make a positive impact on the growth of retail profit to General Juice Plc's, sales volume, market share, and customer loyalty. Several previous studies have shown mixed results in different contexts and countries, and Different variables. According to research by (Massara, Porcheddu, \& Melara, 2019), which was aims at examining the impact of publicity on consumer brand preferences, identifying advertisement channels that influence consumer buying behavior most effectively and identifying factor that encourages consumer brand loyalty, The study found that branding in a lifestyle was linked to high language abstractions; branding in a product was linked to linguistic precision; and construal level was a mediator, which increased willingness to pay at low levels, the research recommended that careful consideration for future studies be required to use descriptive terminology and lifestylebased publicity.

In another research by (A. J. Lee, 2019) which was the purpose of the research is to investigate the dynamic asymmetric impact on the purchasing process of cross-medium exposures, the findings suggest that through the cross-media was the overall effect of television advertising was complex based on its alignment with the previous online visibility, The study suggested study complex synergistic effects that showed asymmetry against TV publicity. Research by (Parsons \& Descatoires, 2016) which was aims to assess the quality of shopping mall offers and consumer reviews, results indicate clear differences between sellers and consumer and indicate possible combinations that would produce optimum customer comportment, the studies recommend Some conventional promotions. Research by Semin et al. (2016) which was the aim to examine the drugs as commercial products, is subject to diverse marketing methods including promotional activities, and to investigate the patients' opinions on the promotional activities of pharmaceutical companies, the result shows Nearly $83 \%$ of the participants were aware of the promotion issue. Eighty percent found it unethical, $82 \%$ suggested that promotional activities should be forbidden, restricted, or regulated. $1 / 3$ of the participants believed that physician made their drug choices based on the gifts \& ads of pharmaceutical company. Half of them had low confidence in the prescriptions of physicians who accepted gifts from pharmaceutical companies. $54.5 \%$ of patients also considered promotional activities as a factor that increased drug prices, the study recommended future research, Further, these regulations must incorporate and take into consideration the patients' opinion.

Previous literature suggested that the five independent variables developed into one single model to influence retail business performance, and It has not been studied in the Nigerian environment. previous discussions regarding the importance of individual variables demonstrated how effective promotional activities can be carried to help the retail business succeed. Different results were published by various researchers including (Kotler, 2016; Ayman Meidan, García-García, Escalona, \& Ramos, 2017). Current research will put together five factors, integrating them into a model for more efficient promotional activities in Nigerian retail companies and thereby enhancing the success of the retail business, and to cover gaps in previous research's and cover more comprehensive factors (advertising, personal sales, direct marketing, promotions of sales, and public relations). 
DOI: $\underline{10.51386 / 25815946 / \text { ijsms-v4i3p113 }}$

Volume: 4 Issue: 3

May to June 2021

www.ijsmsjournal.org

\section{3: RESEARCH FRAMEWORK}

The possibility of interference in the research idea is discussed in a conceptual model. This acts like a map, displaying all possible phases of the research and linking up the activities of the research. This model is a framework that defines, develops, and explains the interlinked research activities (Mathooko \& Ogutu, 2014), beginning at problem description to data analysis. The theoretical framework shows that the model is made up by the primary forecasters for successful promotional practices that affect the performance of the retail business, such as advertising, human resources sales, direct marketing, management promotion and public relations. However, the current study considers a fresh and promising study that can lead to the success of retail companies by incorporating innovative promotional activities. To determine the degree to which the five independent variables (advertising, personal sales, direct marketing, promotion of sales and public relations) are central in their management, successful promotional behavior is investigated further.A research structural model has been developed for the purposes of explaining the research hypotheses referred to in Table 2.2 below. Five hypotheses relating to direct effects between advertising (A), personal selling (PS), direct marketing (DM), sales promotion (SP), public relations (PR) were tested in the structural research model.

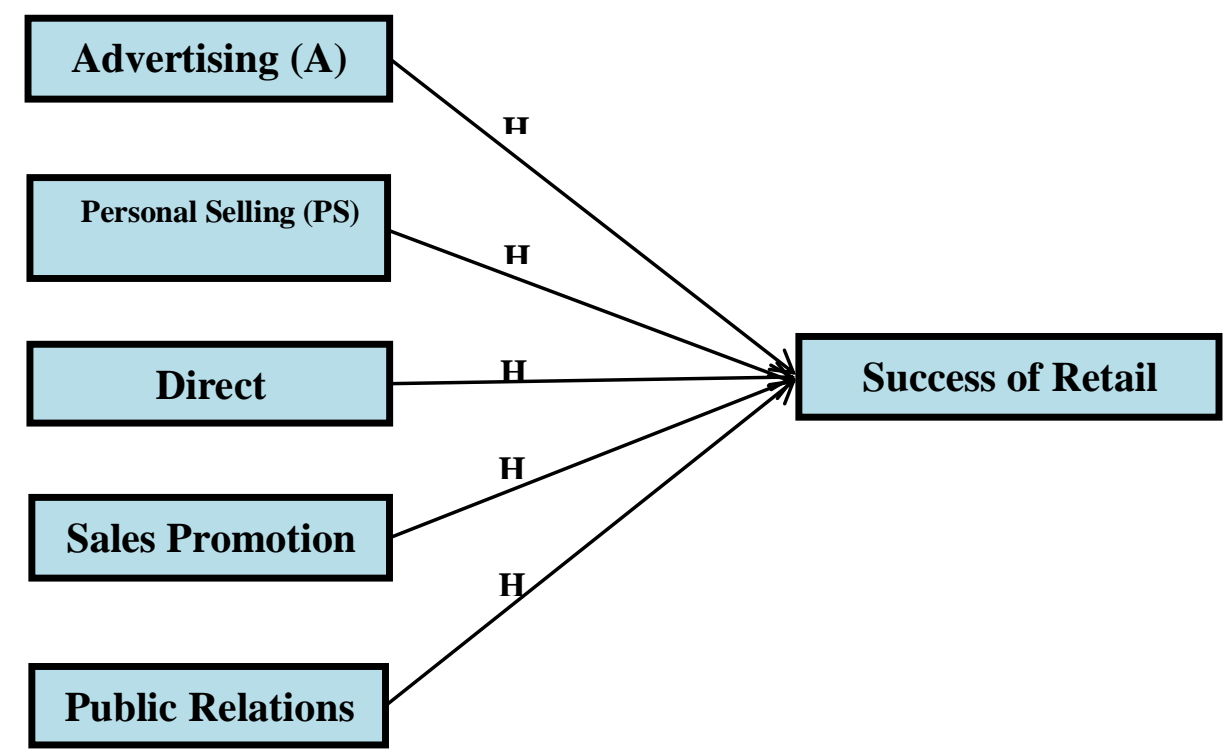

Figure 1 Research Hypotheses in Research Structural Model

Previous literature suggested that the five independent variables developed into one single model to influence retail business performance, and It has not been studied in the Nigerian environment. previous discussions regarding the importance of individual variables demonstrated how effective promotional activities can be carried to help the retail business succeed. Different results were published by various researchers including Kotler (2016) and Meidan (2017). Current research will put together five factors, integrating them into a model for more efficient promotional activities in Nigerian retail companies and thereby enhancing the success of the retail business, and to cover gaps in previous research's and cover more comprehensive factors (advertising, personal sales, direct marketing, promotions of sales, and public relations).

\section{1: Hypotheses Development}

A hypothesis is a proposal to explain or solve the research problem or statement that the relationship between the variables defined in the research question forecasts. An effective hypothesis should be logical, descriptive, and understood to be naturally derived from the process of analysis. Normally, if you deny the zerohypothesis you can claim that the alternative hypothesis is agreed and vice versa, you can use two types, namely the 
DOI: $\underline{10.51386 / 25815946 / \text { ijsms-v4i3p113 }}$

Volume: 4 Issue: 3

May to June 2021

www.ijsmsjournal.org

zero-hypothesis and the alternate hypothesis. Based on the research problem proposed, research question and research goals were postulated above the following zero and alternative hypotheses. Simone (2015). The research hypotheses and codes are shown below in the following table 2.

Table Error! No text of specified style in document.: Research Hypotheses

\begin{tabular}{|c|l|c|}
\hline$\#$ & Description & Path \\
\hline H1 & Advertising significantly affects the Success of Retail Business & A $\rightarrow$ SRB \\
\hline H2 & Personal Selling significantly affects the Success of Retails Business & PS $\rightarrow$ SRB \\
\hline H3 & Direct Marketing significantly affects the Success of Retail Business & DM $\rightarrow$ SRB \\
\hline H4 & Sales Promotion significantly affects the Success of Retail Business & SP $\rightarrow$ SRB \\
\hline H5 & Public Relations significantly affects the Success of Retail Business & PR $\rightarrow$ SRB \\
\hline
\end{tabular}

\section{2: Relationship between Advertising and Success of Retail Business}

Any paid marketing, which is distributed through a mass-media, can be described as advertisement. The sponsor should clearly be defined, and the publicity may relate to a business, a product, or a service (Frances and Stephen, 2006).In order to promote and advertise a product, service or concept (Brassington \& Pettitt, 2006) describe advertisement as a paid non-personally personal communication directed at target people and transmitted by various media. The key difference between ads and other promotional resources is that they are impersonal and interact through paid media outlets with many people. Via mass media like the newspapers, the magazines, the television, or the radio, Phillip Kotler defined advertisement as any paid way of non-personal presentation or promotion of ideas, products, and services. The advertising institute (IPA) has described advertising as how the most compelling message for the right perspective will be delivered at the lowest possible cost. Advertising activities on retail business success are intended to change the site and shape of the retail business ' demand curve. Business creation is one of the sales features. Nevertheless, advertising campaigns are responsible for business growth and product recognition. Promotional activities are an exercise in interrelated knowledge, conviction, and power, which is to be "informed is persuaded," and possibly also told if a person is convinced. With imperfect competition, promotional efforts are necessary. The need for advertising is growing due to the increase in the physical distance between producers and consumers.

Retail business is comprised of the promotional activities related to selling products directly to consumers through channels such as stores, malls, kiosks, vending machines, or other fixed locations (Suguna \& Mathipoorani, 2016). In contrast, direct marketing to consumers attempts to complete a sale through phone, mail, or website sales. The success categorized by the outcome of the promotional activities which is an implementation of the components of the traditional marketing mix that comprises of (product, place, price, and promotion) is essential for success in retail business (Suguna \& Mathipoorani, 2016). (Davidson \& Block, 2015) clarify retailing as the final part of the marketing process in which the various functions of the seller, usually a store or service establishment, and the buyer, an individual consumer is primarily oriented to accomplishing the exchange of economic goods and services, for purposes of personal, family or household use. Although retailing business deals predominantly with the ultimate consumer, it must be recognized that the retail store is only one of several alternative means by which consumers can obtain the products and services they desire (Obaga et al., 2013). Increasingly, consumer expenditures that might have usually gone through the retailing arrangement are being diverted to other types of use markets which are being aggressively served by a variety of both private and public enterprises. Based on the above, the following hypothesis was developed:

\section{H1: Advertising significantly affects the Success of Retail Business}

\section{2. $\quad$ Relationship between Personal Selling and Success of Retails Business}

Personal selling is an advocacy combination that allows advertisers to face consumer contact to sell their product to the customer. This component of the promotional mix has the elements of feedback message or response about the quality of the product. Brassington \& Pettitt (2010) describe personal sales as a two-way communication mechanism between an organization's representative and an individual or community with a view to informing, persuading, or recalling, or serve them in taking proper action. Personal sales are also a key element in maintaining customer satisfaction and building long-term, confidence and understanding buyer-seller ties.(Verhallen et al., 
DOI: $\underline{10.51386 / 25815946 / \text { ijsms-v4i3p113 }}$

1997)reported that increased competition has contributed to the establishment and preservation of established relationships with consumers within the rapidly evolving world of quality products. Moreover,(Julian \& Ramaseshan, 1994) notes that long-term relationships between individuals are a major factor in achieving a competitive advantage for manufacturing companies. (Arthur Meidan, 1996)notes that it is unlikely that if a customer chooses a new product. Personal sales are therefore probably the most critical factor in the manufacturing contact cycle. (H. L. Lee, 2002)states that personal sales can be made either directly or using digital instruments such as the Internet. Personal sales are oral contact with potential product buyers to sell and establish a connection. The priority of personal sales may be the development of a connection with the potential buyer, but inevitably the end of the sales must end" (H. Ayuba \& Baita).

Retail business is comprised of the promotional activities related to selling products directly to consumers through channels such as stores, malls, kiosks, vending machines, or other fixed locations (Suguna \& Mathipoorani, 2016). In contrast, direct marketing to consumers attempts to complete a sale through phone, mail, or website sales. The success categorized by the outcome of the promotional activities which is an implementation of the components of the traditional marketing mix that comprises of (product, place, price, and promotion) is essential for success in retail business (Suguna \& Mathipoorani, 2016). (Davidson \& Block, 2015) clarify retailing as the final part of the marketing process in which the various functions of the seller, usually a store or service establishment, and the buyer, an individual consumer is primarily oriented to accomplishing the exchange of economic goods and services, for purposes of personal, family or household use. Although retailing business deals predominantly with the ultimate consumer, it must be recognized that the retail store is only one of several alternative means by which consumers can obtain the products and services they desire (Obaga et al., 2013). Increasingly, consumer expenditures that might have usually gone through the retailing arrangement are being diverted to other types of use markets which are being aggressively served by a variety of both private and public enterprises. Based on the above, the following hypothesis was developed:

\section{$>$ H2: Personal Selling significantly affects the Success of Retails Business}

\subsection{2: Relationship between Direct Marketing and Success of Retail Business}

Direct marketing involves direct communication on a one-to-one basis with selected target customers to get an immediate reaction and cultivate lasting customer relations. Use mail, fax, telephone, email, internet, etc. For instance. Direct marketing includes direct one-to-one communication with selected target clients for immediate response and the development of lasting customer relations. E.g., by mail, fax, phone, e-mail, internet, etc. The marketing of new products, advertisements or business announcements may be part of this program. Small companies must meet the unique needs of the consumers to whom the message is sent while creating the message for direct marketing promotion. For clear categories of the population, small companies may use direct marketing. If a local company that sells kids' toys begins a new line for kids, for example, it will target its client list based on those that in the past six months have already purchased toys specifically for kids. The company will email the client list of the new product line and have a specific incentive for that customer base to buy.

Retail business is comprised of the promotional activities related to selling products directly to consumers through channels such as stores, malls, kiosks, vending machines, or other fixed locations (Suguna \& Mathipoorani, 2016). In contrast, direct marketing to consumers attempts to complete a sale through phone, mail, or website sales. The success categorized by the outcome of the promotional activities which is an implementation of the components of the traditional marketing mix that comprises of (product, place, price, and promotion) is essential for success in retail business (Suguna \& Mathipoorani, 2016). (Davidson \& Block, 2015) clarify retailing as the final part of the marketing process in which the various functions of the seller, usually a store or service establishment, and the buyer, an individual consumer is primarily oriented to accomplishing the exchange of economic goods and services, for purposes of personal, family or household use. Although retailing business deals predominantly with the ultimate consumer, it must be recognized that the retail store is only one of several alternative means by which consumers can obtain the products and services they desire (Obaga et al., 2013). Increasingly, consumer expenditures that might have usually gone through the retailing arrangement are being diverted to other types of use markets which are being aggressively served by a variety of both private and public enterprises. Based on the above, the following hypothesis was developed: 
DOI: $\underline{10.51386 / 25815946 / \text { ijsms-v4i3p113 }}$

Volume: 4 Issue: 3

May to June 2021

www.ijsmsjournal.org

\section{H3: Direct Marketing significantly affects the Success of Retail Business}

\subsection{3: Relationship between Sales Promotion and Success of Retail Business}

(Brassington \& Pettitt, 2000)says that promotional promotion is various methods of tactical marketing, most of which have short-term incentives, intended to give added value to the product or service to achieve sales or commercial aims. (Arthur Meidan, 1996) also states that it has two characteristics. First, it gives "a negotiating opportunity," as there is an appealing quality for many sales promoters that provides a deal that is not yet available for purchase. The disadvantage, however, is that even though a significant number of customers are attracted, other clients appear to be less committed to brands in the long term. Secondly, if sales promotions are used too frequently and carelessly, they can lead to unsafe customers and worry about a reliable or reasonably priced service. The promotion of purchases aims at giving consumers additional value as a reward for immediate sales. This incentive can be aimed at customers, distributors, and sales representatives. Purchase's promotions may be an important part of the messaging or advertising mix and are often strategically important in the rapidly changing market for consumer goods for the number three and four brands (Fill, 2006).

The promotion of sales is a method aimed at increasing the selling of a product or services. This may include a promotional campaign, increased effort for public relations, a free sample campaign, the selling of free gifts or trade stamps, the organization of presentations or exhibitions, contests with desirable awards, temporary cuts in price rates, door-to-door calls, informal telemarketing letters and other means (H. Ayuba \& Baita).Retail business is comprised of the promotional activities related to selling products directly to consumers through channels such as stores, malls, kiosks, vending machines, or other fixed locations (Suguna \& Mathipoorani, 2016). In contrast, direct marketing to consumers attempts to complete a sale through phone, mail, or website sales. The success categorized by the outcome of the promotional activities which is an implementation of the components of the traditional marketing mix that comprises of (product, place, price, and promotion) is essential for success in retail business (Suguna \& Mathipoorani, 2016). (Davidson \& Block, 2015) clarify retailing as the final part of the marketing process in which the various functions of the seller, usually a store or service establishment, and the buyer, an individual consumer is primarily oriented to accomplishing the exchange of economic goods and services, for purposes of personal, family or household use. Although retailing business deals predominantly with the ultimate consumer, it must be recognized that the retail store is only one of several alternative means by which consumers can obtain the products and services they desire (Obaga et al., 2013). Increasingly, consumer expenditures that might have usually gone through the retailing arrangement are being diverted to other types of use markets which are being aggressively served by a variety of both private and public enterprises. Based on the above, the following hypothesis was developed:

\section{$>$ H4: Sales Promotion significantly affects the Success of Retail Business}

\subsection{4: Relationship between Public Relations and Success of Retail Business}

It is a broad set of communication activities that is used to create and maintain favorable relations between the organization and its public at no charge (most of the time). Public relation is communication in news story form, regarding organization or its products or service which is transmitted through a mass medium at no charge (Davis, 2018). It needs to cultivate effective media relations and targeting publicity to key markets area viewed as the highest priorities. According to (Kotler \& Keller, 2011), public relation is defined as a planned effort by an organization to influence some group's attitude or opinion towards that organization. The target market of the public relations effort may be any given public such as customers, a government agency or people living near the promoting organization. (Kotler \& Keller, 2011)Public relation influences the opinion of various groups. It can show the company to be a leader in its industry or as an innovator. It can illustrate the company's public spirited and aware of social responsibilities. Public relation uses similar media to that of advertising, however, unlike advertising; it does not normally promote a single theme. It is highly specialized activity requiring a constant flow of press release about the company, its operations, products or services and employees. These are adapted to the needs and styles of the chosen medium. It is also a sophisticated technique of communication to a much wider range of audiences then advertising or sales promotion. Nevertheless, it must form an integrated part of the entire communication mix and indirectly support its sister activities in this mix (Ibid). 
DOI: $\underline{10.51386 / 25815946 / \text { ijsms-v4i3p113 }}$

Volume: 4 Issue: 3

May to June 2021

www.ijsmsjournal.org

The advantage of public relations is that a strong impact it can have on public awareness at a much lower costs than do advertising. The company does not pay for the space or time in the media. Rather, it pays for a staff to develop and circulate information and to manage events. If the company develops an interesting story, it could be picked up by several different media, having the same effect as advertising that would cost millions of dollars. And it would have more credibility than advertising (Kotler \& Keller, 2011). Retail business is comprised of the promotional activities related to selling products directly to consumers through channels such as stores, malls, kiosks, vending machines, or other fixed locations (Suguna \& Mathipoorani, 2016). In contrast, direct marketing to consumers attempts to complete a sale through phone, mail, or website sales. The success categorized by the outcome of the promotional activities which is an implementation of the components of the traditional marketing mix that comprises of (product, place, price, and promotion) is essential for success in retail business (Suguna \& Mathipoorani, 2016). (Davidson \& Block, 2015) clarify retailing as the final part of the marketing process in which the various functions of the seller, usually a store or service establishment, and the buyer, an individual consumer is primarily oriented to accomplishing the exchange of economic goods and services, for purposes of personal, family or household use. Although retailing business deals predominantly with the ultimate consumer, it must be recognized that the retail store is only one of several alternative means by which consumers can obtain the products and services they desire (Obaga et al., 2013). Increasingly, consumer expenditures that might have usually gone through the retailing arrangement are being diverted to other types of use markets which are being aggressively served by a variety of both private and public enterprises. Based on the above, the following hypothesis was developed:

\section{$>$ H5: Public Relations significantly affects the Success of Retail Business}

\section{Conclusion}

This study shows that promotional practices (advertising, direct marketing, sales promotion, and public relations) play a significant role and influence in marketing management, as empirical findings are consistent with results of this research. Promotional activities (advertising, direct marketing promotion and public sales) are important tools for the survival, maintenance, and expansion of businesses. Promotional activities to customer needs and satisfaction should be developed. The promotional operation will concentrate specifically on the long-term competitive advantage of the company, its clients, rivals, and other stakeholders in their long-term mutual relations. The promotional tools should be valued and used, and the right activities should continue to be balanced to be fair in the ever-evolving market environment. Based on the conclusions of chapter four, however, promotional activities have made an important contribution to the success of the retail business. The relationship between variables (advertising, personal sales, direct marketing and product promotion and Public Relations) and success of the retail business It was positive. To enhance the success of retail organizations, promotional activities increase customer loyalties, build confidence, and stimulate demand on an entire basis.

\section{Reference}

[1] Ahmed, A. (2019). Examples of Company Rites \& Rituals. Small Business-Chron. com

[2] Albers, S., Krafft, M., \& Mantrala, M. (2010). Special section on enhancing sales force productivity. International Journal of Res earch in Marketing, 1(27), 44-45.

[3] Austin ,E. W., \& Pinkleton, B. E. (2015). Strategic public relations management: Planning and managing effective communication campaigns: Routledge.

[4] Ayuba, B. (2014). Assessment of Factors Influencing Consumer Satisfaction: A Survey of Customers of Nigerian Manufacturing Companies. Assessment, 4.(3)

[5] Ayuba, B. (2019). The Effects of Unethical Marketing Practices on Nigerian Economy and the Quest for National Development. Archives of Business Research, 7.(6)

[6] Ayuba, B., \& Aliyu, I. A. (2016). The Impact of Product Planning on Customer Loyalty: A Study of Customers of Selected Soft-drinks Manufacturing Companies in Nigeria. International Journal of Management Science Research, 1(1), 175.

[7] Ayuba, B., \& Kurfi, A. (2013). Evaluation of factors influencing strategic marketing on the performance of manufacturing companies in Nigeria. International Journal of Marketing and Technology, 3(10), 158. 
[8] Ayuba, H., \& Baita, A. J. Determinants of Entrepreneurs' Attitude toward Islamic Banking Products in Kano Metropolis, Nigeria .

[9] Belch, G. E., \& Belch, M. A. (2003). Advertising and promotion: An integrated marketing communications perspective: The McGrawHill.

[10] Blattberg, R. C., Briesch, R., \& Fox, E. J. (1995). How promotions work. Marketing science, 14(3_supplement), G122-G1.32

[11] Blattberg, R. C., \& Neslin, S. A. (1989). Sales promotion: The long and the short of it. Marketing letters, 1(1), 81-97.

[12] Blattberg, R. C., \& Neslin, S. A. (1990). Sales promotion: Concepts, methods, and strategies: Prentice Hall.

[13] Brassington, F\& ,.Pettitt, S. (2000). Principles of marketing (Vol. 134): Financial Times Prentice Hall Englewood cliffs, NJ.

[14] Brassington, F., \& Pettitt, S. (2006). Principles of marketing: Pearson Education.

[15] Camilleri, M. A. (2018). Travel marketing, tourism economics andthe airline product: An introduction to theory and practice: Springer.

[16] Churchill, G. A., \& Iacobucci, D. (2006). Marketing research: methodological foundations: Dryden Press New York.

[17] Davidson, L., \& Block, W. E. (2015). Bitcoin, the Regression Theorem , and the emergence of a new medium of exchange. Quarterly Journal of Austrian Economics, 18(3), 311.

[18] Davis, J. F. (1997). Maintaining customer relationships through effective database marketing: a perspective for small retailers. Journal of Marketing Theory and Practice, 5(2), 31-42.

[19] Davis, J. F. (2018). Selling whiteness?-A critical review of the literature on marketing and racism. Journal of Marketing Management, $34(1-2), 134-177$.

[20] Englis, B. G., \& Solomon, M. R. (1997). Special session summary I am not therefore, I am: The role of avoidance products in shaping consumer behavior. ACR North American Advances.

[21] Fill, C. (2006). Simply marketing communications: Pearson Education.

[22] Fill, C., \& Turnbull, S. (2019). Marketing Communications: Touchpoints, Sharing and Disruption: Pearson UK.

[23] French, D., Ryan, C. L., \& Mayson, S. W. (2016). Mayson, French \& Ryan on company law: Oxford University Press.

[24] Getz, D., \& Carlsen, J. (2000). Characteristics and goals of family and owner-operated businesses in the ruraltourism and hospitality sectors. Tourism management, 21(6), 547-560.

[25] Gregory, A. (2020). Planning and managing public relations campaigns: A strategic approach: Kogan Page Publishers.

[26] Hsieh, A. T., \& Li, C. K. (2008). The moderating effect of brand imageon public relations perception and customer loyalty. Marketing intelligence \& planning.

[27] Julian, C. C., \& Ramaseshan, B. (1994). The Role of Customer-contact Personnel in the Marketing of a Retail Bank' s Services. International Journal of Retail \& Distribution Management.

[28] Key, T. M., \& Czaplewski, A. J. (2017). Upstream social marketing strategy: An integrated marketing communications approach. Business Horizons, 60(3), 325-333.

[29] Kotler, P. (1994). Reconceptualizing marketing: an interview with PhilipKotler. European Management Journal, 12(4), $353-361$.

[30] Kotler, P. (2016). A framework for marketing management: Pearson Education Limited.

[31] Kotler, P., \& Keller, K. (2011). Marketing management 14th edition: prentice Hall.

[32] Kuntner, T., \& Teichert, T .(2016).The scope of price promotion research: An informetric study. Journal of Business Research, 69(8), 2687-2696.

[33] Lamb, C., Hair, J., \& McDaniel, C. (2000). Marketing (Cincinnati, OH). South-Western College Publication.

[34] Lee, A. J. (2019). U-statistics: Theory and Practice: Routledge. 
DOI: $\underline{10.51386 / 25815946 / \text { ijsms-v4i3p113 }}$

Volume: 4 Issue: 3

May to June 2021

www.ijsmsjournal.org

[35] Lee, H. L. (2002). Aligning supply chain strategies with product uncertainties. California management review, 44(3), 105-119.

[36] Leković, B., \& Marić, S. M. (2015). Measures of small business success/performance-importance, reliability and usability. Industrija, 43.(2)

[37] Lucianetti, L., Battista, V., \& Koufteros, X. (2019). Comprehensive performance measurement systems design and organizational effectiveness. International Journal of Operations \& Production Management.

[38] Lucky, E .O.-I., Olusegun, A. I., \& Bakar, M. S. (2012). Determinants of Business Success: Trust or Business Policy? Researchers World, $3(3), 37$.

[39] Markman, G. D., \& Baron, R. A. (2003). Person-entrepreneurship fit: why some people are more successful as entrepreneurs than others. Human resource management review, 13(2), 281-301.

[40] Massara, F., Porcheddu, D., \& Melara, R. D. (2019). Luxury brands pursuing lifestyle positioning: effects on willingness to pay. Journal of Brand Management, 26(3), 291-303.

[41] Mathooko, F.M., \& Ogutu, M. (2014). Coping strategies adopted by public universities in Kenya in response to environmental changes.

[42] Meidan, A. (1996). Customer behaviour and market segmentation Marketing Financial Services (pp. 23-49): Springer.

[43] Meidan, A., García-García, J. A., Escalona, M., \& Ramos, I. (2017). A survey on business processes management suites. Computer Standards \& Interfaces, 51, 71-86.

[44] Neslin, S. A. (1989). Sales Promotion: The Long and the Short of It. Marketing letters, 1(1), 81-97.

[45] Nzelibe ,G. C. O., \& Ezekiel, B. D. J. (2019). Redesigning Entrepreneurship Curriculum in Nigerian Universities For Knowledge Creation And Labor Market Competition. Nile Journal of Business and Economics, 4(10), 3-18.

[46] O’Guinn, A. Semenik.(2006). Advertising and Integrated Brand Promotion.(4th ed.) Mason, OH: Thomson.

[47] Obaga, I. M., Omido, K., Garashi, H. M., Odera, O., \& Ogutu, M. (2013). Analysis of retail marketing strategies on Organizational competitiveness. International Journal of Management \& Information Technology, 3(2), 2278-5612.

[48] Ode, M., Babayeju, A., \& Obalowu, M. (2013). Low students' enrolment in home economics programme: A case study of University of Ilorin. Research on humanities and social sciences, 3(14), 46-53.

[49] Odugbesan, O., \& Osuagwu, L. (1 .(999Marketing Promotions and Sales Management. Lagos: Pumark Nigeria Limited, 11.

[50] Parsons, A. G., \& Descatoires, E. (2016). Retail marketing: A novel research agenda. Australasian Marketing Journal (AMJ), $24(2), 102-$ 107.

[51] Peattie, S., \& Peattie, K. (19 .(94Sales promotion. The marketing book, 3, 534-554.

[52] Porter, M. E., \& Kramer, M. R. (2002). The competitive advantage of corporate.

[53] Ramaseshan, B., \& Patton, M. A. (1994). Factors influencing international channel choice of small business exporters. International Marketing Review.

[54] Richard, P. J., Devinney, T. M., Yip, G. S., \& Johnson, G. (2009). Measuring organizational performance: Towards methodological best practice. Journal of management, 35(3), 718-804.

[55] Ross, J., \& Harradine, R. (2010). Value brands: cheap or trendy? Journal of Fashion Marketing and Management: An International Journal.

[56] Shah, S. S. H., Aziz, J., Jaffari, A. R., Waris, S., Ejaz, W., Fatima, M., \& Sherazi, S. K. (2012). The merits and consequences of promotional work are underlined. Successful promotional activity has become a critical inspiring perspective on the retail world, whether business or another enterprise. Asian Journal of Business Management, 4(2), 105-110.

[57] Shamout, M. D., \& Emeagwali, O. L. (2016). Examining the impact of electronic supply chain management processes on customer satisfaction: A literature review. Business and Economic Horizons (BEH), 12(1232-2017-2395), 141-163.

[58] Simpson, K. (2004). 'Doing development': The gap year, volunteer-tourists and a popularpractice of development. Journal of International Development: The Journal of the Development Studies Association, 16(5), 681-692. 
DOI: $\underline{10.51386 / 25815946 / \text { ijsms-v4i3p113 }}$

Volume: 4 Issue: 3

May to June 2021

www.ijsmsjournal.org

[59] Solomon, M. R., Surprenant, C., Czepiel, J. A., \& Gutman, E. G. (1985). A role theory perspective on dyadic interactions :the service encounter. Journal of marketing, 49(1), 99-111.

[60] Stoelhorst, J. W., \& Van Raaij, E. M. (2004). On explaining performance differentials: Marketing and the managerial theory of the firm. Journal of Business Research, 57(5), 462-477.

[61] Suguna, P\&,.Mathipoorani, V. (2016). Strategies for retail marketing. Partnership, 34, 28.23.

[62] Sunday, O. J., \& Ayuba, B. 1. M. Sc. Student, Department of Business Administration, University of Abuja, Gwagwalada, Abuja, FCTNigeria 2. Department of Business Administration, University of Abuja, Gwagwalada, Abuja, FCT-Nigeria.

[63] Tan, P. J., \& Bogomolova, S. (2016). A descriptive analysis of consumer's price promotion literacy skills. International Journal of Retail \& Distribution Management.

[64] Tandoh, I. (2016). Financial Products \& Services Marketing to the Unbanked Population in Ghana. A Case Study of Atwima Kwanwoma Rural Bank Limited (Akrb).

[65] Upadhaya, B., Munir, R., Blount, Y., \& Su, S. (2018). Does organizational culture mediate the CSR-strategy relationship? Evidence from a developing country, Nepal. Journal of Business Research, 91, 108-122.

[66] Verhallen, T. M., Greve, H., \& Frambach, R. T. (1997). Consultative selling in financial services: an observational study of the mortgage mediation process. InternationalJournal of Bank Marketing.

[67] Walker, E., \& Brown, A. (2004). What success factors are important to small business owners? International small business journal, 22(6), 577-594. 